\title{
Carbon mineralization and carbonate preservation in modern cold-water coral reef sediments on the Norwegian shelf
}

\author{
L. M. Wehrmann ${ }^{1,2}$, N. J. Knab ${ }^{1}$, H. Pirlet ${ }^{3}$, V. Unnithan ${ }^{4}$, C. Wild ${ }^{2}$, and T. G. Ferdelman ${ }^{1}$ \\ ${ }^{1}$ Biogeochemistry Research Group, Max Planck Institute for Marine Microbiology, Celsiusstrasse 1, 28359 Bremen, Germany \\ ${ }^{2}$ Coral Reef Ecology Work Group (CORE), GeoBio-Center, Ludwig-Maximilians Universität, Richard-Wagner-Strasse 10, \\ 80333 München, Germany \\ ${ }^{3}$ Renard Centre of Marine Geology, Department of Geology and Soil Science, Ghent University, Krijgslaan 281 s.8, \\ 9000 Gent, Belgium \\ ${ }^{4}$ School of Engineering and Science, Jacobs University Bremen, Campus Ring 1, 28759 Bremen, Germany
}

Received: 13 October 2008 - Published in Biogeosciences Discuss.: 17 December 2008

Revised: 2 April 2009 - Accepted: 2 April 2009 - Published: 27 April 2009

\begin{abstract}
Cold-water coral ecosystems are considered hotspots of biodiversity and biomass production and may be a regionally important contributor to carbonate production. The impact of these ecosystems on biogeochemical processes and carbonate preservation in associated sediments were studied at Røst Reef and Traenadjupet Reef, two modern (post-glacial) cold-water coral reefs on the MidNorwegian shelf. Sulfate and iron reduction as well as carbonate dissolution and precipitation were investigated by combining pore-water geochemical profiles, steady state modeling, as well as solid phase analyses and sulfate reduction rate measurements on gravity cores of up to $3.25 \mathrm{~m}$ length. Low extents of sulfate depletion and dissolved inorganic carbon (DIC) production, combined with sulfate reduction rates not exceeding $3 \mathrm{nmol} \mathrm{S} \mathrm{cm}{ }^{-3} \mathrm{~d}^{-1}$, suggested that overall anaerobic carbon mineralization in the sediments was low. These data showed that the coral fragment-bearing siliciclastic sediments were effectively decoupled from the productive pelagic ecosystem by the complex reef surface framework. Organic matter being mineralized by sulfate reduction was calculated to consist of $57 \%$ carbon bound in $\mathrm{CH}_{2} \mathrm{O}$ groups and $43 \%$ carbon in $-\mathrm{CH}_{2}$ - groups. Methane concentrations were below $1 \mu \mathrm{M}$, and failed to support the hypothesis of a linkage between the distribution of coldwater coral reefs and the presence of hydrocarbon seepage. Reductive iron oxide dissolution linked to microbial sulfate reduction buffered the pore-water carbonate system and inhibited acid-driven coral skeleton dissolution. A large pool of reactive iron was available leading to the formation of iron
\end{abstract}

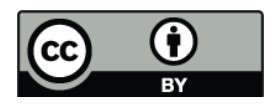

Correspondence to: L. M. Wehrmann (lwehrman@mpi-bremen.de) sulfide minerals. Constant pore-water $\mathrm{Ca}^{2+}, \mathrm{Mg}^{2+}$ and $\mathrm{Sr}^{2+}$ concentrations in most cores and decreasing $\mathrm{Ca}^{2+}$ and $\mathrm{Sr}^{2+}$ concentrations with depth in core 23-18 GC indicated diagenetic carbonate precipitation. This was consistent with the excellent preservation of buried coral fragments.

\section{Introduction}

Marine surface sediments constitute an important element of the global carbonate cycle. They link carbonate production in the surface ocean with the deep subsurface sedimentary environment (Ridgwell and Zeebe, 2005), but also provide an important record of the ocean's response to changing climate conditions in the past (Broecker and Clark, 2001, 2003; Crowley, 1983). While warm-water coral reefs are considered to contribute substantially to marine carbonate production (Milliman, 1993; Vecsei, 2004), the role of cold-water coral ecosystems remains poorly understood. Initial estimates indicate that cold-water coral reefs can be a regionally important contributor to the $\mathrm{CaCO}_{3}$ budget and account for $>1 \%$ of the global $\mathrm{CaCO}_{3}$ production (Lindberg and Mienert, 2005).

Cold-water coral ecosystems, dominated by the azooxanthellate, stony corals Lophelia pertusa and Madrepora oculata, occur in patches and well-established reef systems, but they can also build up enormous carbonate mounds (Roberts et al., 2006). Cold-water corals are widespread at a range of water depths $(30-4000 \mathrm{~m})$ along continental margins, seamounts and banks (Wheeler et al., 2007). Recent studies highlight these thriving ecosystems as hot-spots of biodiversity as well as biomass production, revealing a

Published by Copernicus Publications on behalf of the European Geosciences Union. 
benthic community exceeding 1300 species associated with this habitat (Jensen and Frederiksen, 1992; Mortensen et al., 1995; Roberts et al., 2006; and references therein).

Previous studies have suggested an internal control linking micro-seepage of deep thermogenic hydrocarbons to coral reef occurrence on continental shelves (Hovland et al., 1998; Hovland and Risk, 2003; Hovland and Thomsen, 1997). The authors propose a model in which the migration of hydrocarbons into the water column locally "fertilizes" the ambient seawater with organic and inorganic compounds fueling thriving microbial and coral communities. In an alternative hypothesis, several others suggest that external current- and density-controlled mechanisms govern coral reef distribution and growth (Dorschel et al., 2007; De Mol et al., 2002; Frederiksen et al., 1992; Mienis et al., 2007; Mortensen et al., 2001; White et al., 2005, 2007b; White, 2007a). This external reef development theory is further supported by the recent study of Dullo et al. (2008), which showed a preferential coral settlement, including Røst Reef and Traenadjupet Reef, in water masses of a density of $27.5 \pm 0.15 \mathrm{~kg} / \mathrm{m}^{3}$.

Results from Integrated Ocean Drilling Program (IODP) Expedition 307, which drilled Challenger cold-water coral mound in the Porcupine Seabight, provide the first insight into biogeochemical processes in ancient cold-water coral reef systems (Ferdelman et al., 2006). Decreasing pore-water sulfate and increasing alkalinity concentrations and diagnostic pore-water distributions of $\mathrm{Ca}^{2+}, \mathrm{Mg}^{2+}$ and $\mathrm{Sr}^{2+}$ indicate a coupling between microbial-mediated organic matter degradation and carbonate-mineral diagenesis (Ferdelman et al., 2006). Furthermore, the authors propose that hydrogen sulfide produced during microbial-mediated sulfate reduction reacts with ferric-iron-containing minerals to form iron sulfides, leading to pore-water sulfide depletion. Observations on the occurrence of preferential coral skeleton preservation alternating with zones of poor carbonate preservation (Ferdelman et al., 2006) and distinct recurring cycles exhibiting changes in carbonate content and color reflectance (Titschack et al., 2009) suggest a linkage between sediment composition and coral skeleton preservation. Overall, the findings from IODP Expedition 307 indicate a tight coupling between the sulfur, carbon and iron cycles in sediments associated with cold-water coral reef environments.

Several studies (e.g. Boudreau and Canfield, 1993; Ku et al., 1999; Walter et al., 1993; Walter and Burton, 1990) have shown that the relationship between sulfate reduction, hydrogen sulfide oxidation and iron-sulfide mineral formation can drive carbonate dissolution and precipitation in shallow marine sediments. Best et al. (2007) noted that shell preservation of bivalve shells is enhanced in siliciclastic sediments compared to carbonate dominated sediments. A recent comparison of bauxite-contaminated and uncontaminated sites at Discovery Bay, Florida, (Perry and Taylor, 2006) revealed carbonate grain dissolution at the uncontaminated sites compared to the contaminated sites, where carbonates are preserved. The authors attributed the carbonate preservation to the availability of sufficient reactive iron in the bauxite-contaminated sediments. Existing models suggest that the production of hydrogen sulfide and bicarbonate in reactive iron-poor sediments can lead to carbonate dissolution depending on the magnitude of organoclastic sulfate reduction (Ben-Yaakov, 1973; Gardner, 1973; Walter and Burton, 1990). In contrast, if sediments contain a sufficient pool of reactive iron, hydrogen sulfide produced during sulfate reduction reacts with dissolved iron constituents and iron(oxyhydr)oxides to form iron sulfides (Berner, 1970, 1984) and carbonate undersaturation is prevented (Ben-Yaakov, 1973; Soetaert et al., 2007).

The aim of this study is to investigate how modern coldwater coral reefs influence the adjacent sediment and associated geochemical processes and to provide a framework for understanding carbonate preservation patterns in nontropical carbonate-rich sediments. The near-shore cold-water coral reefs on the Norwegian shelf serve as an excellent environment to investigate carbonate dynamics in carbonate-rich, siliciclastic sediments receiving a sufficient input of terrigenous material (in particular reactive iron phases). We present data on sulfate reduction rates, diagnostic pore-water profiles $\left(\mathrm{Ca}^{2+}, \mathrm{Mg}^{2+}, \mathrm{Sr}^{2+}\right.$, dissolved $\mathrm{Mn}$ and $\mathrm{Fe}, \mathrm{SO}_{4}^{2-}$ and $\mathrm{HS}^{-}$, DIC and alkalinity) and solid-phase analyses (TIC, TOC, Fe phases) of seven gravity cores retrieved at Røst Reef and Traenadjupet Reef, located south-west of the Lofoten islands, during R/V Polarstern expedition ARK XXII/1a in June 2007.

\section{Study area}

\subsection{Røst Reef}

Røst Reef, discovered in 2002, is regarded as the largest living cold-water coral reef in the world (Nordgulen et al., 2006; Thorsnes et al., 2004). It is located on the northern midNorwegian continental slope immediately north-east of the Vøring Plateau at a water depth of 300-400 m (Fig. 1a and b). It covers steep ridges originating from the Traenadjupet landslide, one of several submarine landslides that have taken place on the Norwegian continental margin during late Cenozoic times (Damuth, 1978). Deposits from this most recent landslide (approximately $4000{ }^{14} \mathrm{C}$ years BP), cover an area of about $9100 \mathrm{~km}^{3}$ (Laberg and Vorren, 2000). The ridges comprise mostly glaciogenic debris-flow deposits and glaciomarine sediments (Laberg et al., 2002a). They have a maximum length of up to $1 \mathrm{~km}$, reach several tens of meters above the surrounding seafloor, and occur in a very dense spacing (Laberg et al., 2002a). Post-slide hemipelagic sediment deposition varies strongly throughout the Røst Reef region, with the thickest sediment cover found in the small depressions between the ridges immediately inside the slide scar and with minimal sediment deposition occurring along the headwall due to strong currents (Laberg et al., 2002b). 
The ridge morphology leads to a distinct habitat zonation of the reef (Fig. 2). Ridge tops are covered by a dense framework of living coral colonies forming terraces towards the lee-side. The upper parts of the slopes consist of glacial clay followed by a coral rubble-dominated facies ("coral rubble zone") on the lower slopes. The depressions between the ridges comprise fine-grained, clay to silt-dominated matrix with embedded coral fragments ("clay zone").

Surface currents down to $800 \mathrm{~m}$ water depth in the Røst Reef region are driven by the confluence of the Norwegian coastal current entering the area from the south. These northeastward-orientated strong currents flow approximately parallel to the Røst Reef (Laberg et al., 2002b; Poulain et al., 1996).

\subsection{Traenadjupet Reef}

The Traenadjupet Reef area, first described by Hovland and Mortensen (1999), is located in a sheltered embayment on the edge of Traenadjupet, an elongated cross-shelf trough on the mid-Norwegian shelf (Ottesen et al., 2005) (Fig. 1a and c). Studies suggest that the trough formed an important pathway for ice-sheet drainage during Fennoscandian Ice Sheet coverage (Ottesen et al., 2005). The reef is situated on top of Oligocene deltaic sandy fan deposits forming distinct cigarshaped structures at 300-330 m water depth (Hovland et al., 2005).

Traenadjupet Reef is exposed to a cyclonic circulation predominating in the Lofoten basin (Poulain et al., 1996). It does not feature a distinct habitat zonation comparable to Røst Reef. Instead, living corals only cover a few eastern tips of these structures while most cigar-shaped tops consist of dense coral rubble. The lower parts of the structures are covered by a fine-grained matrix of silt to clay and biogenic debris.

\section{Material and methods}

\subsection{Sample collection}

Sediment samples were collected during R/V Polarstern cruise ARK XXII/1a to the mid-Norwegian margin in June 2007. Locations for sediment sampling were selected based on video reconnaissance during the cruise with the research submersible Jago (GEOMAR-Kiel). At Røst Reef, cores were taken from the different reef zones (Fig. 2). Cores from Traenadjupet Reef were sampled from the lower parts of the cigar-shaped structures. Sampling locations and water depths of the cores presented in this paper are summarized in Table 1 . In total, 7 sediment cores of $0.42-3.25 \mathrm{~m}$ length were retrieved at water depths of $323-527 \mathrm{~m}$ with a gravity corer (GC; $12 \mathrm{~cm}$ ID). They were cut into $1-\mathrm{m}$ sections immediately after core retrieval and the sediment temperature was measured at the top of each section. Sections were stored at $4^{\circ} \mathrm{C}$ until further processing. Sub-samples for solid-phase
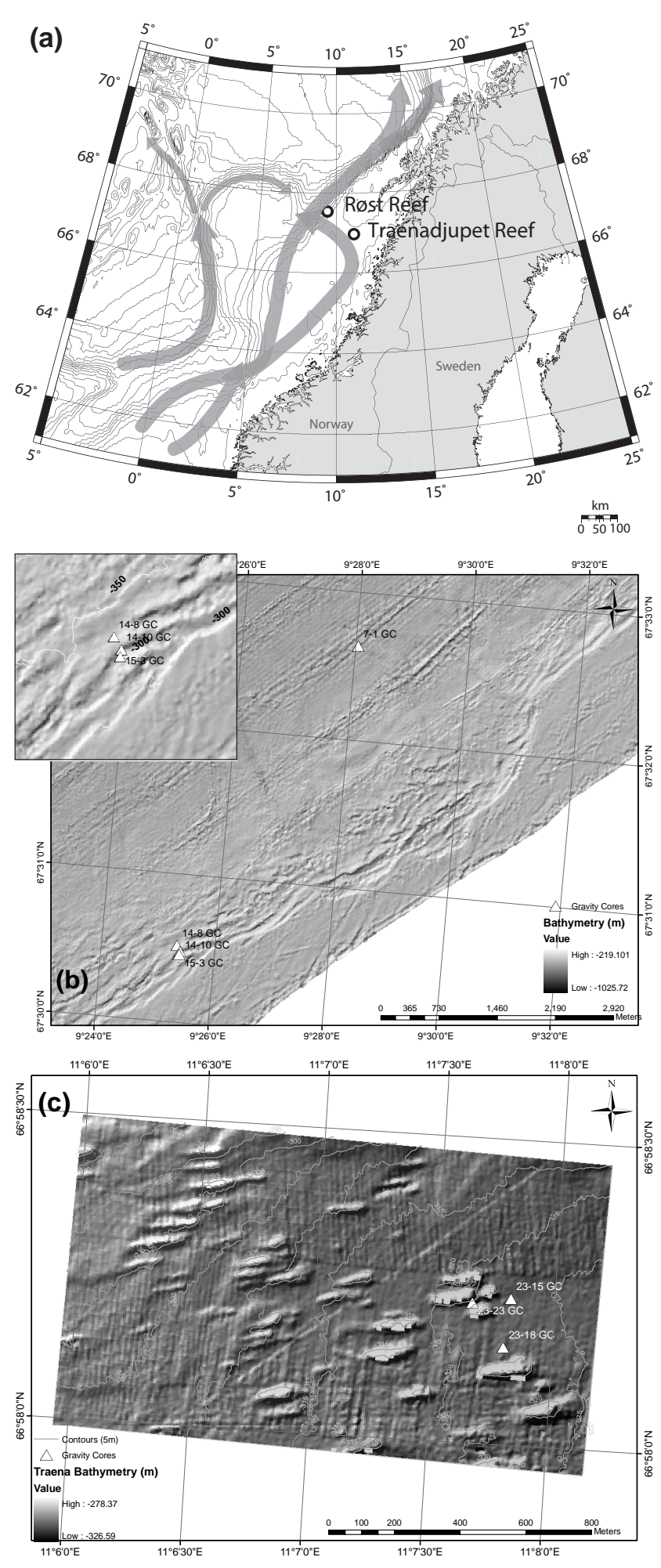

Fig. 1. (a) Map of the Norwegian Sea with the two investigated reefs (white circles) and the schematic surface water circulation (adapted from Poulain et al., 1996; gray arrows). (b) Bathymetric map of Røst Reef location. (c) Bathymetric map of Traenadjupet Reef location. Both maps include the positions of the retrieved gravity cores. 
Table 1. Sampling location, water depth, core length and core identification.

\begin{tabular}{lllllll}
\hline Reef & Latitude $\left({ }^{\circ} \mathrm{N}\right)$ & Longitude $\left({ }^{\circ} \mathrm{E}\right)$ & Water depth $(\mathrm{m})$ & Core length $(\mathrm{cm})$ & Core identification & Site description \\
\hline Røst Reef & $67^{\circ} 32.64$ & $9^{\circ} 28.05$ & 527 & 42 & $7-1 \mathrm{GC}$ & Off-reef \\
& $67^{\circ} 30.52$ & $9^{\circ} 25.34$ & 324 & 115 & $14-8 \mathrm{GC}$ & Clay zone \\
& $67^{\circ} 30.48$ & $9^{\circ} 25.40$ & 330 & 53 & $14-10 \mathrm{GC}$ & Reef top \\
Traenadjupet Reef & $67^{\circ} 30.46$ & $9^{\circ} 25.39$ & 331 & 163 & $15-3 \mathrm{GC}$ & Coral rubble zone \\
& $66^{\circ} 58.24$ & $11^{\circ} 7.82$ & 327 & 55 & $23-15 \mathrm{GC}$ & Off-reef \\
& $66^{\circ} 58.16$ & $11^{\circ} 7.80$ & 327 & 325 & $23-18 \mathrm{GC}$ & Reef, reactive core \\
& $66^{\circ} 58.23$ & $11^{\circ} 7.66$ & 323 & 109 & $23-23 \mathrm{GC}$ & Reef \\
\hline
\end{tabular}

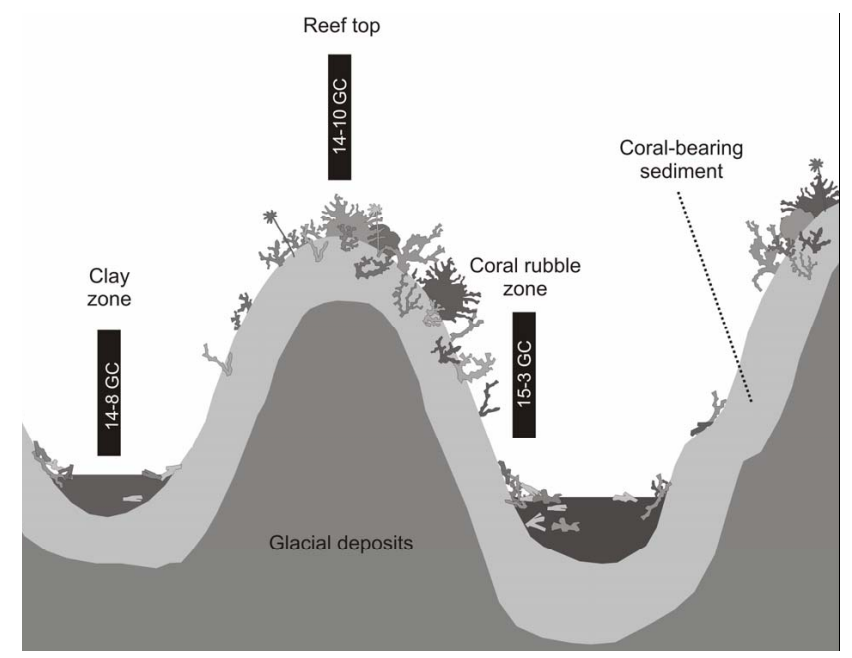

Fig. 2. Schematic of Røst Reef zonation.

and pore-water analyses, as well as for sulfate reduction rate measurements, were taken from the cores within a few hours after core retrieval. An overview of measurements applied on the different cores is given in Table 2.

\subsection{Solid-phase analyses}

Samples for solid-phase analyses were taken at $5 \mathrm{~cm}$ intervals in the top $2 \mathrm{~m}$ and at $10 \mathrm{~cm}$ intervals throughout the remaining core. Samples were frozen immediately at $-20^{\circ} \mathrm{C}$. Frozen samples were freeze-dried, and all coral pieces were removed from the dried samples prior to sample powdering. Total carbon (TC) was determined with a Carlo Erba NA$1500 \mathrm{CNS}$ analyzer using in-house standard (DAN1). Total inorganic carbon (TIC) was measured using a CM $5012 \mathrm{CO}_{2}$ Coulometer (UIC) after acidification with phosphoric acid (3 M). Precisions $(2 \sigma)$ were $0.2 \mathrm{wt} . \%$ for TC and $0.1 \mathrm{wt} \%$ for TIC. Total organic carbon (TOC) was calculated as the difference between TC and TIC.

A sequential extraction procedure based on Poulton and Canfield (2005) was used to quantify the solid-phase iron pools in cores 15-3 GC and 23-18 GC. The extraction al-
Table 2. Overview of measurements applied on the cores. + indicates conducted measurements. $(+)$ indicates that the measurement has been conducted but values are below detection limit.

\begin{tabular}{|c|c|c|c|c|c|c|c|c|}
\hline Reef & $\begin{array}{l}\text { Core } \\
\text { identi- } \\
\text { fication }\end{array}$ & $\begin{array}{l}\mathrm{TC} / \\
\mathrm{TIC} / \\
\mathrm{TOC}\end{array}$ & $\begin{array}{l}\text { Sequen- } \\
\text { tial } \\
\text { Fe-ex- } \\
\text { traction }\end{array}$ & $\begin{array}{l}\text { AVS/ } \\
\text { CRS }\end{array}$ & $\mathrm{SO}_{4}^{2-}$ & $\begin{array}{l}\text { ICP- } \\
\text { OES }\end{array}$ & $\begin{array}{l}\text { DIC/ } \\
\text { TA }\end{array}$ & SRR \\
\hline Røst & $7-1 \mathrm{GC}$ & + & & & + & & & $(+)$ \\
\hline Reef & $\begin{array}{l}14-8 \mathrm{GC} \\
14-10 \mathrm{GC}\end{array}$ & $\begin{array}{l}+ \\
+\end{array}$ & & & $\begin{array}{l}+ \\
+\end{array}$ & $\begin{array}{l}+ \\
+\end{array}$ & + & + \\
\hline & $15-3 \mathrm{GC}$ & + & + & + & + & + & + & + \\
\hline Traena- & $23-15 \mathrm{GC}$ & + & & & + & + & & $(+)$ \\
\hline djupet & $23-18 \mathrm{GC}$ & + & + & + & + & + & + & + \\
\hline Reef & $23-23$ GC & + & & & + & + & + & + \\
\hline
\end{tabular}

lowed for the determination of carbonate-associated and adsorbed $\mathrm{Fe}\left(\mathrm{Fe}_{\mathrm{carb}}\right.$, extraction by sodium acetate), easily reducible $\mathrm{Fe}-\left(\right.$ oxyhydr)oxides $\left(\mathrm{Fe}_{\mathrm{ox} 1}\right.$, hydroxylamine- $\left.\mathrm{HCl}\right)$, reducible Fe-(oxyhydr)oxides ( $\mathrm{Fe}_{\mathrm{ox} 2}$, sodium dithionite), magnetite $\left(\mathrm{Fe}_{\mathrm{mag}}\right.$, ammonium oxalate) and poorly reactive silicate $\mathrm{Fe}\left(\mathrm{Fe}_{\mathrm{PRS}}\right.$, concentrated $\left.\mathrm{HCl}\right)$. The remaining fraction of unreactive $\mathrm{Fe}$ bound as sheet silicates was not quantified during these analyses. Fe analyses were performed by atomic absorption spectrometry (Perkin Elmer). Additionally, acid volatile sulfide $\left(\mathrm{AVS}=\mathrm{H}_{2} \mathrm{~S}+\mathrm{FeS}\right)$ and chromium reducible sulfur $\left(\mathrm{CRS}=\mathrm{FeS}_{2}+\mathrm{S}^{0}\right)$ were determined on frozen sub-samples of the same cores using a two-step Cr-II method with cold $2 \mathrm{M} \mathrm{HCl}$ and boiling $0.5 \mathrm{M} \mathrm{CrCl}_{2}$ solution (Fossing and Jørgensen, 1989). Fe $_{\text {carb }}$ determined during the sequential Fe extraction was corrected for AVS, because sodium acetate treatment results in the complete dissolution of all $\mathrm{Fe}$ bound as FeS (Poulton and Canfield, 2005). Fe contents obtained by the sequential extraction procedure, AVS and CRS were corrected for wet-to-dry-weight ratio. Sequential Fe extraction on the sediment samples were conducted in duplicate and generally varied by $5 \%$ or less within one extraction sequence and $10 \%$ for different sequence runs. 


\subsection{Pore-water analyses}

Pore-water samples were obtained with Rhizones (Rhizosphere Research Products, Wageningen, Netherlands) attached to $5 \mathrm{ml}$ plastic syringes (Seeberg-Elverfeldt et al., 2005). For the determination of $\mathrm{SO}_{4}^{2-}, \mathrm{Cl}^{-}$and $\mathrm{H}_{2} \mathrm{~S}$ concentrations aliquots were fixed by adding $\mathrm{ZnAc}(2 \%, \mathrm{w} / \mathrm{v})$. $\mathrm{SO}_{4}^{2-}$ and $\mathrm{Cl}^{-}$concentrations were obtained after 100:1 dilution by non-suppressed anion exchange chromatography as described in Ferdelman et al. (1997). IAPSO standard seawater (Canada) was used as reference standard. Precisions $(2 \sigma)$ for $\mathrm{SO}_{4}^{2-}$ and $\mathrm{Cl}^{-}$measurements were $0.6 \mathrm{mM}$ and $0.025 \mathrm{M}$, respectively.

$\mathrm{H}_{2} \mathrm{~S}$ concentrations were determined from the fixed samples by the diamine complexation method using $\mathrm{N}, \mathrm{N}$-dimethyl-1,4-phenylendiamine-dihydrochloride according to Cline (1969) and subsequent spectrophotometrical measurement at a wavelength of $670 \mathrm{~nm}$. Detection limit of the analyses was $1 \mu \mathrm{M}$.

For multi-element pore-water analyses $\left(\mathrm{Fe}_{\text {diss }}\right.$ and $\mathrm{Mn}_{\text {diss }}$, $\mathrm{Ca}^{2+}, \mathrm{Mg}^{2+}$ and $\mathrm{Sr}^{2+}$ ), 1-2 $\mathrm{ml}$ aliquots were acidified to $1 \% \mathrm{HNO}_{3}(\mathrm{v} / \mathrm{v})$. Samples were analyzed directly from 10fold diluted samples by inductively coupled plasma optical emission spectroscopy (ICP-OES) using CASS-4 and IAPSO standard seawater (Canada) as reference standards. Precision $(2 \sigma)$ for ICP-OES was $<4 \%$ for all elements.

Pore-water aliquots for measurement of dissolved inorganic carbon (DIC) and total alkalinity (TA) were poisoned with $\mathrm{HgCl}_{2}(0.25 \mathrm{mM})$ and sealed headspace-free in $2 \mathrm{ml}$ glass-vials. DIC concentrations were determined by flowinjection (Hall and Aller, 1992). Total alkalinity (TA) was determined by the Gran titration method (Gieskes and Rogers, 1973) on 1:2 (v/v) diluted samples. Precisions $(2 \sigma)$ for DIC and TA determination were $0.4 \mathrm{mM}$ and $0.2 \mathrm{mM}$, respectively.

The PHREEQC 2.14.3 program (Parkhurst and Appelo, 1999) was used to calculate activities and the saturation index (SI) of aragonite and calcite in core 23-18 GC with $\mathrm{SI}=0$ representing equilibrium, $\mathrm{SI}<0$ showing undersaturation and $\mathrm{SI}>0$ showing oversaturation of the mineral with respect to the pore-water solution.

\subsection{Methane concentration measurements}

Methane concentrations were determined from $3 \mathrm{~cm}^{3}$ sediment samples stored upside-down in gas-tight glass bottles containing $6 \mathrm{ml} \mathrm{NaOH}(2.5 \%$, w/v). Headspace methane concentrations were measured by injection of an aliquot of the gas headspace into a gas chromatograph (Hewlett Packard 5890A) equipped with a packed stainless steel Porapak-Q column (6 ft., 0.125 in., 80/100 mesh Agilent Technologies) and a flame ionization detector. Helium was used as carrier gas at a flow of $2 \mathrm{ml} \mathrm{min}^{-1}$.

\subsection{Sulfate reduction rate measurements}

Sulfate reduction rates (SRR) were determined in triplicate on-board after subsampling of the GC cores at $5 \mathrm{~cm}$ intervals for the upper $2 \mathrm{~m}$ and $10 \mathrm{~cm}$ intervals in the lower part of the cores. Sediment was sampled in $5 \mathrm{ml}$ glass tubes that were sealed with butyl rubber stoppers. After injection of ${ }^{35} \mathrm{~S}_{-} \mathrm{SO}_{4}^{2-}(200 \mathrm{kBq})$ samples were incubated for $20-24 \mathrm{~h}$ at in-situ temperatures in the dark. The incubation period was terminated by transferring the samples into vials containing $20 \mathrm{ml} \mathrm{ZnAc} \mathrm{(20 \% ,} \mathrm{w/v).} \mathrm{Reduced} \mathrm{radiolabeled} \mathrm{sul-}$ fur was separated by the cold distillation method described by Kallmeyer et al. (2004) and SRR were calculated after Jørgensen (1978) from the sulfate concentration per $\mathrm{cm}^{3}$ sediment, the total amount of ${ }^{35} \mathrm{~S}_{-} \mathrm{SO}_{4}^{2-}$ in the sample and the amount of total reduced inorganic sulfur species.

\subsection{Pore-water geochemical modeling}

Measured pore-water profiles of $\mathrm{SO}_{4}^{2-}$, DIC and $\mathrm{Ca}^{2+}$ of core $23-18$ GC were interpreted using the PROFILE modeling procedure developed by Berg et al. (1998). This numerical modeling procedure fits a series of least-square equations to the concentration profiles. By assuming steady-state conditions and including molecular diffusion, bioturbation and irrigation the net rate of consumption or production of the dissolved species as a function of depth can be calculated using

$\frac{d}{d z}\left(\varphi D_{s} \frac{d C}{d z}\right)+\varphi \alpha\left(C_{o}-C\right)+R=0$

where $\varphi$ is the porosity, $z$ is the depth, $D_{s}$ is the molecular diffusivity, $C$ is the pore-water concentration, $C_{0}$ is the bottom water concentration, $\alpha$ is the irrigation coefficient and $R$ is the net of production (if $R>0$ ) or consumption (if $R<0$ ). The PROFILE model divides the profiles into a number of zones of constant areal production/consumption rates that can be displayed with the modeled concentration profile. Additionally, it calculates the flux of the dissolved species across the sediment-water interface. In order to successfully reproduce the measured concentration profiles, specific boundary conditions are used at the top and bottom of each profile allowing the input of concentrations or fluxes into the model. In our calculations, pore-water concentrations at the sediment top and at $318 \mathrm{~cm}$ depth were used to set boundary conditions. $D_{s}$ was calculated according to Schulz (2000) as:

$D_{s}=\frac{D^{0}}{\theta^{2}}$

where $D^{0}$ is the temperature-dependent diffusion coefficient of the component in free solution for seawater and $\theta$ is the tortuosity. Values for $\theta$ were calculated based on the relationship (Boudreau, 1997):

$\theta^{2}=1-\ln \left(\varphi^{2}\right)$ 
Bioirrigation was neglected as we observed no evidence of bioturbation or bioirrigation at depth below $10 \mathrm{~cm}$.

\section{Results}

\subsection{Sediment composition}

The three cores taken from the different zones of Røst Reef (Fig. 2) show differences in sediment composition and color. Core 14-10 GC taken at the reef top comprise a mixture of coarse sand, a few cobbles and biogenic debris. The biogenic debris consists of abundant mollusk shells and high numbers of coral skeleton fragments of $L$. pertusa and M. oculata in the top $50 \mathrm{~cm}$ of the core. Below $50 \mathrm{~cm}$ the core consists of sandy sediment with some silt to clay containing minor biogenic debris without coral fragments. Core 15-3 GC, taken in the "coral rubble zone", is topped by a $13 \mathrm{~cm}$ thick layer of brown to black coral rubble and biogenic debris with minor mud infill. Below this layer, the sediment is gray and consists of large coral fragments embedded in loose silt, clay and biogenic debris. Beneath $50 \mathrm{~cm}$ sponge remains attached to corals fragments are frequently observed. The sediment in this core becomes more compact with increasing depth but still contains abundant coral fragments. At $158 \mathrm{~cm}$ sediment depth, a sharp transition to very compact bluish clay and absence of coral fragments indicate the reef base and underlying glacial ridge deposits. Core 14-8 GC ("clay zone") lacks a coral rubble layer, but is comprised of coral fragments embedded in a matrix of silty clay and bioclasts throughout the core. At $9 \mathrm{~cm}$ sediment depth a change in sediment color from brownish-gray to gray occurs. At Røst Reef, sediments are underlain by dark clay indicating that the reef formed directly on top of the ridges of the Traenadjupet landslide. Off-reef core 7-1 GC reveals that sediments away from the reef consist of cohesive, very compact clay with only few biogenic clasts.

Sediment at Traenadjupet Reef is composed of varying amounts of coral fragments and coral rubble of $L$. pertusa and $M$. oculata in a matrix of loose silty clay, biogenic debris and minor cobbles. The sediment color changes from brownish-gray to gray around $7-9 \mathrm{~cm}$ in both cores taken from this reef (23-18 GC and 23-23 GC). In core 23-18 GC sponge remains replace the buried corals at $122-130 \mathrm{~cm}$ sediment depth. A sharp change in sediment color and composition in the deeper part of both cores from this reef indicates the bottom of the reef. Underlying sediments are comprised of bluish clay that contains stones, probably of glacial origin. Off-reef sediments (23-15 GC) in this area consist of dark silt to clay with a varying sand fraction and sponge spicules.

At both, Røst and Traenadjupet Reef, coral fragments from the top sediment horizons are coated with a brownish crust similar to the coatings of coral fragments retrieved from the surface of other cold-water coral reefs (Freiwald et al., 1997). These crusts are only present within the upper $10-15 \mathrm{~cm}$ of the sediments; with the exception of core $14-8 \mathrm{GC}$, where encrusted corals are found in deeper sediment layers. Sediment directly surrounding corals is often observed to be darker than the adjacent sediment matrix. Microscopic analyses of sediments from both reefs reveal a high content of benthic and planktonic foraminifera, minor percentages of coccolithophores and diatoms and high amounts of sponge spicules. These spicules originate from calcareous as well as siliceous sponges in varying proportions. Bore holes and tubes in the buried coral fragments indicate the colonization of living and dead corals by benthic boring organisms such as sponges, bryozoans and polychaetes. Despite these signs of bioerosion, no visual signs for chemical dissolution of the coral pieces could be observed.

\subsection{Solid-phase analyses}

A summary of the average TC, TIC and TOC contents of the investigated cores from Røst Reef and Traenadjupet Reef is given in Table 3. Sediments from both reefs are characterized by high TIC contents (Fig. 3) with slightly higher average values of $4.57(1 \sigma \pm 0.97)$ wt.\% at Røst Reef compared to $3.97(1 \sigma \pm 0.87) w t . \%$ at Traenadjupet Reef. Sediments from the surface layer of Røst Reef core 15-3 GC (coral rubble zone) show the highest TIC contents with values of up to 9.05 wt.\%. TOC contents (Fig. 3) in sediments from both reefs are low, with most values below $1 \mathrm{wt} . \%$. Sediments from off-reef cores 7-1 GC and 23-15 GC (Fig. 9) are characterized by average TIC contents $<0.62 \mathrm{wt} . \%$ and average TOC contents $<0.40 \mathrm{wt} . \%$.

Table 4 summarizes the average values for the extracted Fe fractions from cores 15-3 GC (Røst Reef) and 23-18 GC (Traenadjupet Reef). Carbonate-associated $\mathrm{Fe}\left(\mathrm{Fe}_{\text {carb }}\right)$ content $(<0.06$ wt. \% Fe dry weight) in both investigated cores is low while large fractions of easily reducible and reducible $\mathrm{Fe}$-(oxyhydr)oxides $\left(\mathrm{Fe}_{\mathrm{ox} 1}\right.$ and $\mathrm{Fe}_{\mathrm{ox} 2}$; Fig. 4) were found. Magnetite $\left(\mathrm{Fe}_{\mathrm{mag}}\right)$ content in both cores follows trends similar to those of the reactive iron fractions (Fig. 4). Poorly reactive sheet silicate ( $\mathrm{Fe}_{\mathrm{PRS}}$ ) constitutes the largest fraction determined with the sequential extraction method with average values above 1.26 wt.\% Fe (Fig. 4). CRS concentrations of cores 15-3 GC and 23-18 GC are presented in Fig. 5. Core $15-3 \mathrm{GC}$ is characterized by very low CRS concentrations (average 0.04 wt. \% S) while core $23-18$ GC shows larger values for this fraction (CRS average $0.15 \mathrm{wt} . \% \mathrm{~S}$ ). AVS concentrations in both cores are below detection limit.

\subsection{Pore-water analyses}

Pore-water $\mathrm{SO}_{4}^{2-}, \mathrm{Fe}_{\text {diss }}$ and $\mathrm{Mn}_{\text {diss }}$ profiles from cores $14-$ $8 \mathrm{GC}, 14-10 \mathrm{GC}$ and $15-3 \mathrm{GC}$ (Røst Reef) are shown in Fig. 6a, and profiles from cores $23-18 \mathrm{GC}$ and $23-23 \mathrm{GC}$ (Traenadjupet Reef) are shown in Fig. 6b. Figure 9 displays the $\mathrm{SO}_{4}^{2-}$ distribution in off-reef core 7-1 GC (Røst Reef) and $\mathrm{SO}_{4}^{2-}, \mathrm{Fe}_{\text {diss }}$ and $\mathrm{Mn}_{\text {diss }}$ profiles from off-reef 


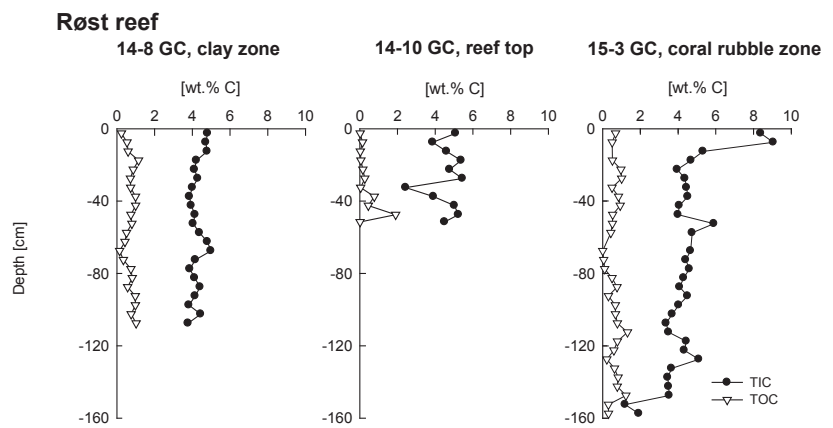

Traenadjupet reef

23-18 GC, reactive core $\quad 23-23 \mathrm{GC}$

[wt.\% C] [wt.\% C]

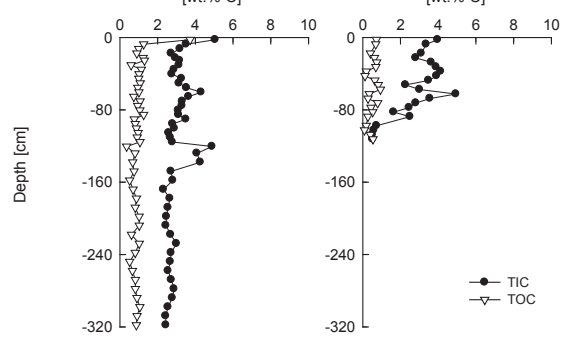

Fig. 3. Solid-phase total inorganic carbon (TIC) and total organic carbon (TOC) content in cores 14-8 GC, 14-10 GC and 15-3 GC from Røst Reef and in cores 23-18 GC and 23-23 GC from Traenadjupet Reef.

Table 3. Average TC, TIC and TOC contents [wt.\%] and standard deviation $(1 \sigma)$ of cores 14-8 GC, 14-10 GC, 15-3 GC (Røst Reef), 23-18 GC and 23-23 GC (Traenadjupet Reef).

\begin{tabular}{lllll}
\hline Reef & Core & TC $[w t . \%]$ & TIC [wt.\%] & TOC [wt.\%] \\
\hline Røst Reef & $14-8$ GC & $4.98( \pm 0.22)$ & $4.27( \pm 0.35)$ & $0.71( \pm 0.26)$ \\
& $14-10 \mathrm{GC}$ & $4.92( \pm 1.10)$ & $4.57( \pm 0.84)$ & $0.35( \pm 0.54)$ \\
& $15-3 \mathrm{GC}$ & $5.18( \pm 1.43)$ & $4.57( \pm 1.44)$ & $0.60( \pm 0.34)$ \\
Traenadjupet & $23-18 \mathrm{GC}$ & $4.03( \pm 0.90)$ & $3.07( \pm 0.62)$ & $0.96( \pm 0.46)$ \\
Reef & 23-23 GC & $3.81( \pm 0.76)$ & $3.28( \pm 0.79)$ & $0.53( \pm 0.23)$ \\
\hline
\end{tabular}

core 23-15 GC (Traenadjupet Reef). The $\mathrm{SO}_{4}^{2-}$ concentrations exhibit small decreases in all reef sites except core 23-18 GC, following a linear trend with a $\mathrm{SO}_{4}^{2-}$ gradient of about $3 \mathrm{mM} \mathrm{m}^{-1}$. In contrast, $\mathrm{SO}_{4}^{2-}$ distribution in core $23-$ $18 \mathrm{GC}$ is characterized by a strong decrease in the top $60 \mathrm{~cm}$ of the core to a concentration of around $18 \mathrm{mM}$ followed by a slow decrease in the deeper parts of the core down to minimum value of around $15 \mathrm{mM}$. Off-reef cores display almost linear $\mathrm{SO}_{4}^{2-}$ profiles. $\mathrm{H}_{2} \mathrm{~S}$ was not detected $(<1 \mu \mathrm{M})$ in any of the retrieved pore-water samples.

In the Røst Reef cores 14-8 GC and 15-3 GC, Fe diss $_{\text {con- }}$ centrations increase from 0 to around $20 \mu \mathrm{M}$ within the top $30 \mathrm{~cm}$ and then decrease gradually with depth to minimum concentrations of $<5 \mu \mathrm{M}$. Pore-water profiles of the latter
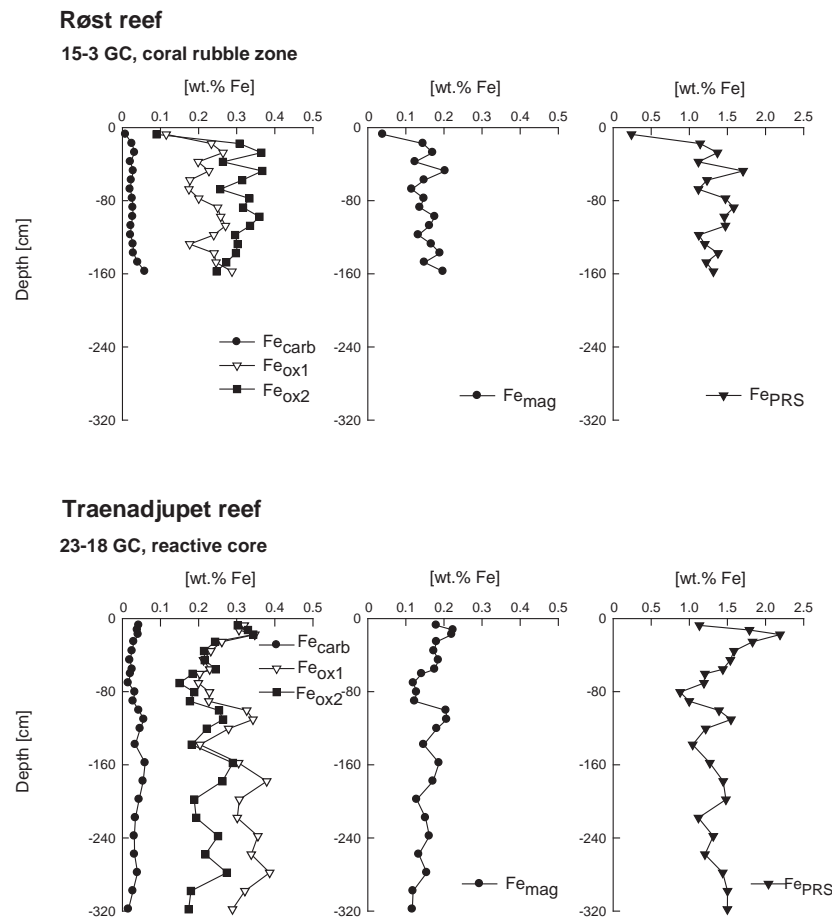

Fig. 4. Results of sequential Fe extractions for cores 15-3 GC (Røst Reef) and 23-18 GC (Traenadjupet Reef); Fractions include $\mathrm{Fe}_{\text {carb }}$, $\mathrm{Fe}_{\mathrm{ox} 1}, \mathrm{Fe}_{\mathrm{ox} 2}, \mathrm{Fe}_{\mathrm{mag}}$ and $\mathrm{Fe}_{\mathrm{PRS}}$.

Table 4. Average values for sequential $\mathrm{Fe}$ extractions partitioning between $\mathrm{Fe}_{\text {carb }}, \mathrm{Fe}_{\mathrm{ox} 1}, \mathrm{Fe}_{\mathrm{ox} 2}, \mathrm{Fe}_{\text {mag }}$ and $\mathrm{Fe}_{\mathrm{PRS}}$ contents [wt.\%] and standard deviation ( $1 \sigma)$ of cores 15-3 GC (Røst Reef) and 2318 GC (Traenadjupet Reef).

\begin{tabular}{lllllll}
\hline Reef & Core & $\begin{array}{l}\mathrm{Fe}_{\text {carb }} \\
{[w t . \%]}\end{array}$ & $\begin{array}{l}\mathrm{Fe}_{\text {ox1 }} \\
{[w t . \%]}\end{array}$ & $\begin{array}{l}\mathrm{Fe}_{\text {ox2 }} \\
\text { [wt.\%] }\end{array}$ & $\begin{array}{l}\mathrm{Fe}_{\text {mag }} \\
\text { [wt.\%] }\end{array}$ & $\begin{array}{l}\mathrm{Fe}_{\text {PRS }} \\
\text { [wt.\%] }\end{array}$ \\
\hline Røst Reef & $15-3 \mathrm{GC}$ & $\begin{array}{l}0.03 \\
( \pm 0.01)\end{array}$ & $\begin{array}{l}0.22 \\
( \pm 0.04)\end{array}$ & $\begin{array}{l}0.30 \\
( \pm 0.06)\end{array}$ & $\begin{array}{l}0.15 \\
( \pm 0.04)\end{array}$ & $\begin{array}{l}1.26 \\
( \pm 0.31)\end{array}$ \\
$\begin{array}{l}\text { Traenadjupet } \\
\text { Reef }\end{array}$ & $23-18 \mathrm{GC}$ & $\begin{array}{l}0.04 \\
( \pm 0.01)\end{array}$ & $\begin{array}{l}0.29 \\
( \pm 0.06)\end{array}$ & $\begin{array}{l}0.23 \\
( \pm 0.05)\end{array}$ & $\begin{array}{l}0.16 \\
( \pm 0.03)\end{array}$ & $\begin{array}{l}1.39 \\
( \pm 0.28)\end{array}$ \\
\hline
\end{tabular}

core reveal increasing $\mathrm{Fe}_{\text {diss }}$ concentrations below $120 \mathrm{~cm}$ depth with a maximum value of $31 \mu \mathrm{M}$ at $147.5 \mathrm{~cm}$. Porewater $\mathrm{Mn}_{\text {diss }}$ profile of $14-8 \mathrm{GC}$ show a linear increase in the top $60 \mathrm{~cm}$ up to values of around $20 \mu \mathrm{M}$. $\mathrm{Mn}_{\text {diss }}$ present in the pore-water of $15-3 \mathrm{GC}$ increase similar to the $\mathrm{Fe}_{\text {diss }}$ concentration in the top $30 \mathrm{~cm}$ reaching values between of 22 and $29 \mu \mathrm{M}$. Both $\mathrm{Fe}_{\text {diss }}$ and $\mathrm{Mn}_{\text {diss }}$ values decrease again in the clay deposits below the reef base. Core 14-10 GC in contrast is characterized by low $\mathrm{Fe}_{\text {diss }}$ concentrations $(<6 \mu \mathrm{M})$ but a strong increase in $\mathrm{Mn}_{\text {diss }}$ concentrations from 0 to $59 \mu \mathrm{M}$ in the top $52 \mathrm{~cm}$ of the sediment.

At Traenadjupet Reef the $\mathrm{Fe}_{\text {diss }}$ profile of core 23-18 GC reveals variable concentrations between 2 and $13 \mu \mathrm{M}$ within the top $148 \mathrm{~cm}$. Between 148 and $178 \mathrm{~cm}$ a concentration 


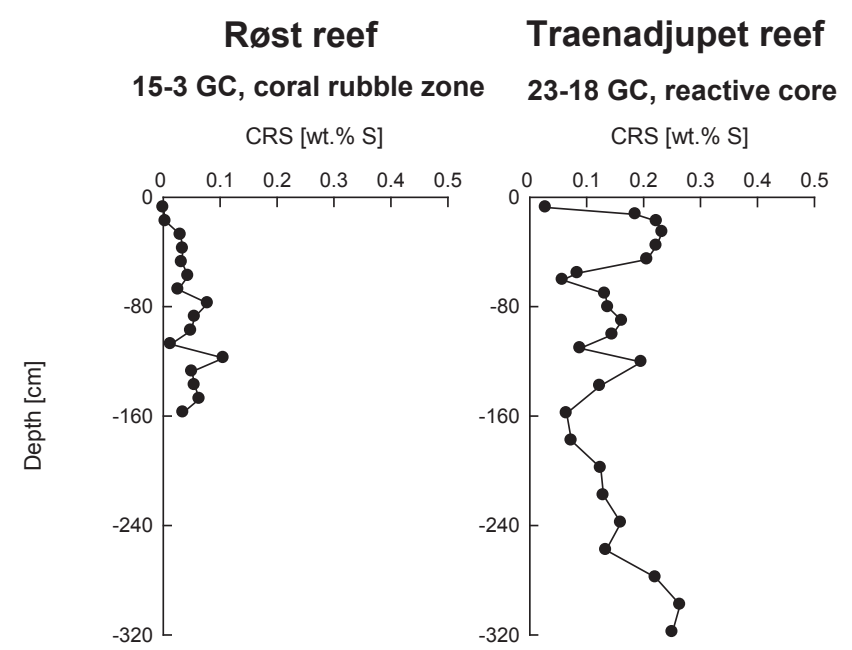

Fig. 5. Chromium reducible sulfur (CRS) distribution in cores 153 GC (Røst Reef) and 23-18 GC (Traenadjupet Reef).

peak occurs with a maximum value of $17 \mu \mathrm{M}$ at $168 \mathrm{~cm}$ depth. $\mathrm{Fe}_{\text {diss }}$ concentrations in core $23-23 \mathrm{GC}$ range from $1 \mu \mathrm{M}$ to a maximum of $47 \mu \mathrm{M}$ at $72.5 \mathrm{~cm}$. Pore-water $\mathrm{Mn}_{\text {diss }}$ concentrations in the Traenadjupet Reef cores show maximum values around $14 \mu \mathrm{M}$. In core $23-18 \mathrm{GC}$ maximum concentrations are reached at $240 \mathrm{~cm}$, while in core 23-23 GC maximum $\mathrm{Mn}_{\text {diss }}$ concentrations are reached at $67.5 \mathrm{~cm}$ sediment depth. Off-reef core 23-15 GC exhibits increases in $\mathrm{Fe}_{\text {diss }}$ and $\mathrm{Mn}_{\text {diss }}$ concentrations in the top $5 \mathrm{~cm}$ to average values of $11 \mu \mathrm{M}$ and $10 \mu \mathrm{M}$, respectively.

Dissolved $\mathrm{Ca}^{2+}, \mathrm{Mg}^{2+}$ and $\mathrm{Sr}^{2+}$ concentrations are displayed in Figs. 7a (Røst Reef) and b (Traenadjupet Reef) and 9 (off-reef core 23-15 GC). Røst Reef cores 14-8 GC, 14-10 GC and 15-3 GC as well as Traenadjupet Reef core 23-23 GC and off-reef core 23-15 GC display constant concentrations for all dissolved constituents close to seawater concentration. In contrast, concentration profiles of core 2318 GC from Traenadjupet Reef show that $\mathrm{Ca}^{2+}$ and $\mathrm{Sr}^{2+}$ concentrations in this core decrease in the top $105 \mathrm{~cm}$. Surface $\mathrm{Ca}^{2+}$ and $\mathrm{Sr}^{2+}$ concentrations start at $10.4 \mathrm{mM}$ and $0.89 \mathrm{mM}$, respectively, and decrease to values of around $5.4 \mathrm{mM}$ and $0.40 \mathrm{mM}$ at $100 \mathrm{~cm}$ sediment depth. $\mathrm{Mg}^{2+}$ concentrations remain constant within the top $200 \mathrm{~cm}$ of the core (average value of $55.0 \mathrm{mM}$ ); below this depth $\mathrm{Mg}^{2+}$ concentrations decrease slightly to minimum values of $53.5 \mathrm{mM}$. In order to exclude salinity changes as the main cause for the decreasing $\mathrm{Ca}^{2+}$ and $\mathrm{Sr}^{2+}$ profiles, the pore-water concentration of the "conservative" ion $\mathrm{Cl}^{-}$for this core was determined. Measured concentrations of $\mathrm{Cl}^{-}$are consistent, averaging $534( \pm 27) \mathrm{mM}$ in the top $160 \mathrm{~cm}$ and $566( \pm 71) \mathrm{mM}$ below this sediment depth (Fig. 6b). $\mathrm{Sr} / \mathrm{Ca}$ and $\mathrm{Mg} / \mathrm{Ca}$ ratios shown in Fig. 7a and b, which can be used to monitor relative changes between different sedimentary carbonate species, are similar in all cores except for core 23-18 GC. $\mathrm{Mg} / \mathrm{Ca}$ ratios in $23-18 \mathrm{GC}$ increase from 5.8 to 10.7 within the top $110 \mathrm{~cm}$. Furthermore, despite a decrease in both $\mathrm{Sr}^{2+}$ and $\mathrm{Ca}^{2+}$ in this core, the $\mathrm{Sr} / \mathrm{Ca}$ ratio steadily decreases from 0.008 to 0.007 with depth.

Pore-water profiles of DIC and TA (Fig. 8) are inversely correlated with the measured $\mathrm{SO}_{4}^{2-}$ profiles. Pore-water data from Røst Reef reveal only minor increases in the top $40 \mathrm{~cm}$ of the cores with average values of $3.6 \mathrm{mM}$ DIC and $3.7 \mathrm{mM}$ TA for 14-8 GC, $2.1 \mathrm{mM}$ DIC and TA for 14-10 GC, $4.2 \mathrm{mM}$ DIC and $4.3 \mathrm{mM}$ TA for $15-3 \mathrm{GC}$. Core $23-23 \mathrm{GC}$ also follows this trend averaging $3.2 \mathrm{mM}$ DIC and TA. Core 23-18 GC again contrasts strongly. DIC and TA exhibit a concave-up profile in the top $60 \mathrm{~cm}$ reaching values around $14 \mathrm{mM}$ and a minor increase in the deeper parts of the sediment to maximum values of $16.7 \mathrm{mM}$ DIC and $16.3 \mathrm{mM}$ TA. Saturation index (SI) values for core 23-18 lie between 0.1 and 1.2 (Fig. 8); calcite is only slightly more saturated than aragonite.

\subsection{Methane concentration measurements}

Methane concentration measurements reveal extremely low methane values below $1 \mu \mathrm{M}$ at all investigated sediment depths in both coral reefs (data not shown).

\subsection{Sulfate reduction rate measurements}

SRR data are very low and do not exceed $3 \mathrm{nmol} \mathrm{S} \mathrm{cm}{ }^{-3} \mathrm{~d}^{-1}$ (Fig. 6a and b). Core 14-8 GC (clay zone) exhibits the highest SRR (averaging $2 \mathrm{nmol} \mathrm{s} \mathrm{cm}{ }^{-3} \mathrm{~d}^{-1}$ ) of all cores with a peak at $7.5-17.5 \mathrm{~cm}$ depth, but with no detectable sulfate reduction below $47.5 \mathrm{~cm}$. However, this core had a higher background signal during the measurement compared to the other cores. In Core 14-10, SRR measurements were not possible due to the extremely high amount of coral fragments. For Røst Reef core 15-3 GC, topped by a layer of coral rubble with only minor sediment infill, SRR measurements were only possible below $15 \mathrm{~cm}$. Here, detected SRR data average $0.22 \mathrm{nmol} \mathrm{S} \mathrm{cm}^{-3} \mathrm{~d}^{-1}$ within the top $120 \mathrm{~cm}$. Below this depth rates decrease to less than $0.10 \mathrm{nmol} \mathrm{S} \mathrm{cm}^{-3} \mathrm{~d}^{-1}$. Detected SRR from Traenadjupet Reef core 23-18 GC show average values of $0.13 \mathrm{nmol} \mathrm{S} \mathrm{cm}{ }^{-3} \mathrm{~d}^{-1}$ at $5-70 \mathrm{~cm}$ sediment depth. Between $70-158 \mathrm{~cm}$ SRR drop $<0.10 \mathrm{nmol} \mathrm{S} \mathrm{cm}^{-3} \mathrm{~d}^{-1}$. At 158 $208 \mathrm{~cm}$ a second peak in detected SRR appears, which averages $0.16 \mathrm{nmol} \mathrm{S} \mathrm{cm}^{-3} \mathrm{~d}^{-1}$. At greater depths no sulfate reduction could be detected. In core $23-23$ GC SRR data are very low $\left(<0.15 \mathrm{nmol} \mathrm{S} \mathrm{cm}^{-3} \mathrm{~d}^{-1}\right)$. Elevated values (up to $0.95 \mathrm{nmol} \mathrm{S} \mathrm{cm}^{-3} \mathrm{~d}^{-1}$ ) only occur at $37.5-42 \mathrm{~cm}$ sediment depth. All SRR measurements for the off-reef cores 7-1 GC and $23-15 \mathrm{GC}$ were below detection limit.

\subsection{Pore-water geochemical modeling}

Modeled pore-water concentrations, delineated zones of consumption and production for $\mathrm{SO}_{4}^{2-}$, DIC and $\mathrm{Ca}^{2+}$ and the corresponding fluxes of these constituents across the 

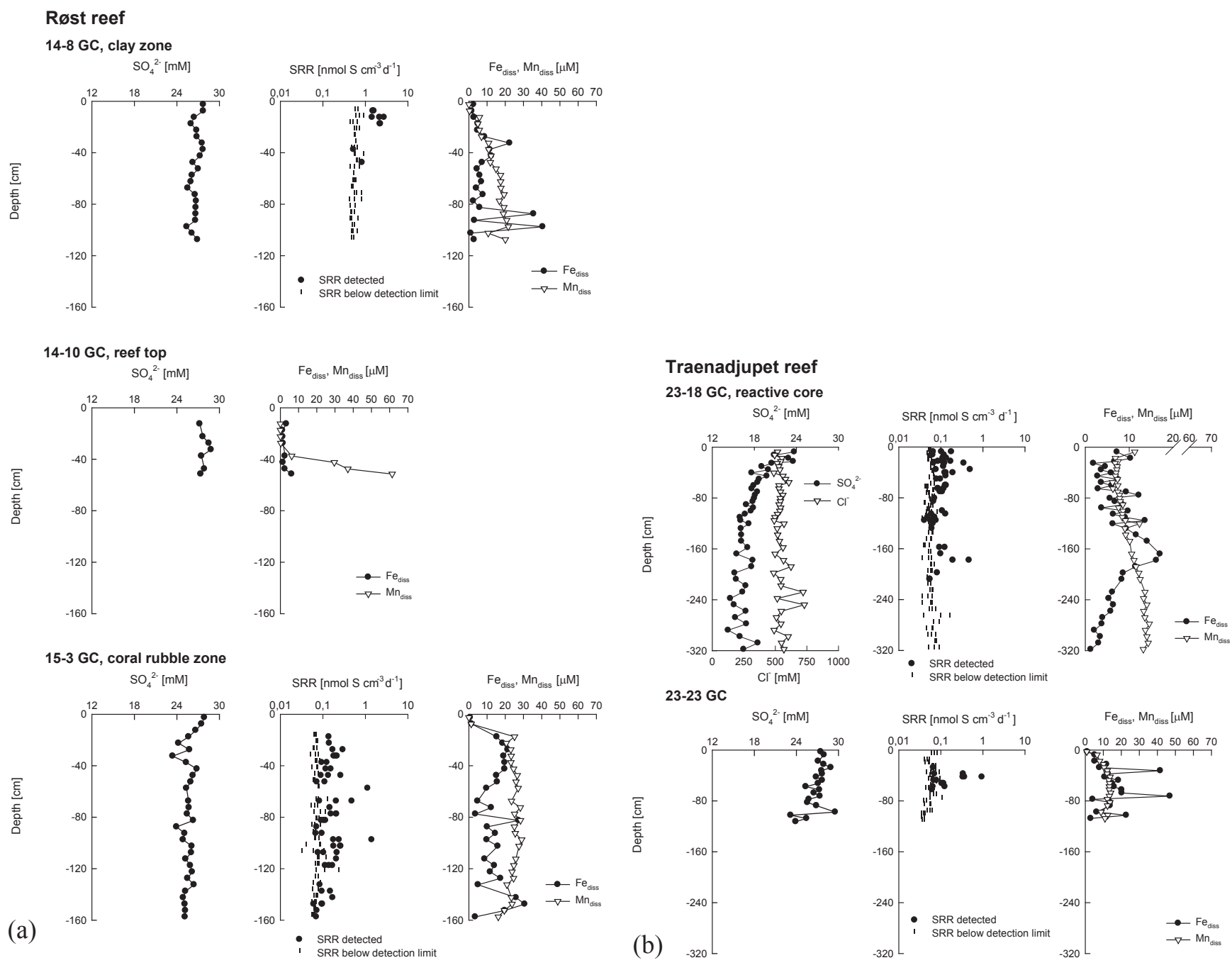

(a)
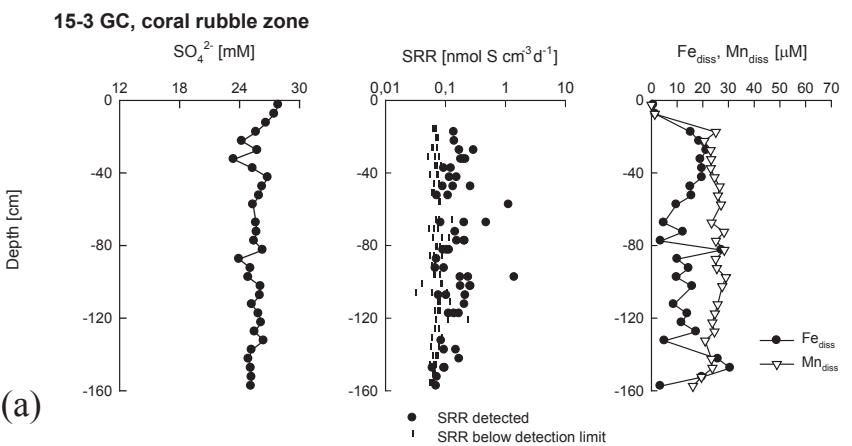

Fig. 6. (a) Pore-water concentration of $\mathrm{SO}_{4}^{2-}$, SRR, dissolved $\mathrm{Fe}\left(\mathrm{Fe}_{\text {diss }}\right)$ and dissolved $\mathrm{Mn}\left(\mathrm{Mn}_{\text {diss }}\right)$ in cores 14-8 GC, 14-10 GC and 153 GC from Røst Reef. (b) Pore-water concentration of $\mathrm{SO}_{4}^{2-}$ and $\mathrm{Cl}^{-}(23-18 \mathrm{GC}), \mathrm{SRR}, \mathrm{Fe}_{\text {diss }}$ and $\mathrm{Mn}_{\text {diss }}$ in cores $23-18 \mathrm{GC}$ and $23-23 \mathrm{GC}$ from Traenadjupet Reef; SRR below calculated minimum detection limit are also plotted.

sediment-water interface for core $23-18 \mathrm{GC}$ are shown in Fig. 10. Interpretation of the $\mathrm{SO}_{4}^{2-}$ profile reveals a major zone of sulfate consumption in the top $106 \mathrm{~cm}$ of the sediment with a consumption rate of $335 \mu \mathrm{mol} \mathrm{m}^{-2} \mathrm{~d}^{-1}$ and a zone of minor consumption in the deeper part of the core $\left(25 \mu \mathrm{mol} \mathrm{m}^{-2} \mathrm{~d}^{-1}\right)$. The DIC profile is characterized by a production zone with a production rate of $412 \mu \mathrm{mol} \mathrm{m}^{-2} \mathrm{~d}^{-1}$ at $0-149 \mathrm{~cm}$ sediment depth and a consumption zone of approximately equal area below this depth with a consumption rate of $163 \mu \mathrm{mol} \mathrm{m}{ }^{-2} \mathrm{~d}^{-1}$. Modeling of the $\mathrm{Ca}^{2+}$ concentration reveals a major zone of consumption in the upper $103 \mathrm{~cm}$ of this core with a consumption rate of $101 \mu \mathrm{mol} \mathrm{m}^{-2} \mathrm{~d}^{-1}$. At greater depths, only small changes in the profile are evident as indicated by a production rate of $0.2 \mu \mathrm{mol} \mathrm{m}^{-2} \mathrm{~d}^{-1}$.

\section{Discussion}

\subsection{Microbial-mediated organic carbon mineralization}

Distributions of pore-water metabolites such as $\mathrm{SO}_{4}^{2-}$, DIC, and $\mathrm{Fe}_{\text {diss }}$ and $\mathrm{Mn}_{\text {diss }}$, combined with direct rate measurements reveal extremely low rates of anaerobic carbon mineralization in the investigated cold-water coral reef sediments. Organoclastic sulfate reduction appears to be the dominant electron donating process in these sediments. Rates of sulfate reduction shown in Fig. 6a and b, however, do not exceed detected rates of $3 \mathrm{nmol} \mathrm{S} \mathrm{cm}^{-3} \mathrm{~d}^{-1}$ at any site. These values are clearly higher than at the reference sites outside the coral reefs where no sulfate reduction was detected, but rates are very low in comparison to other high-latitude shelf areas, where sulfate reduction generally dominates microbialmediated organic carbon mineralization (Jørgensen, 1982; 
Røst reef

14-8 GC, clay zone
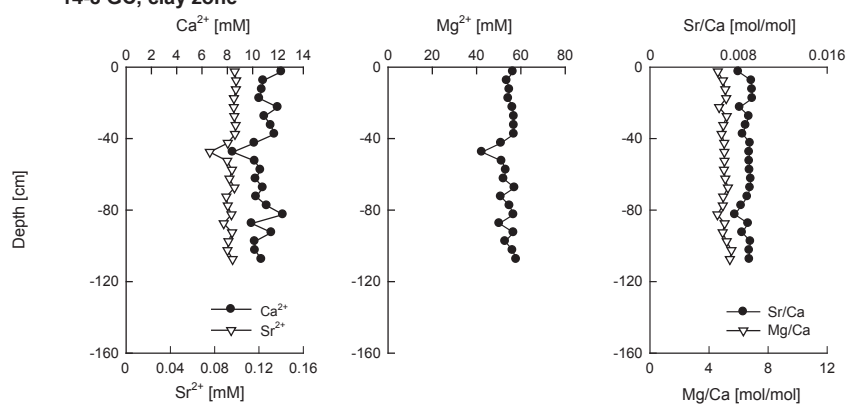

14-10 GC, reef top
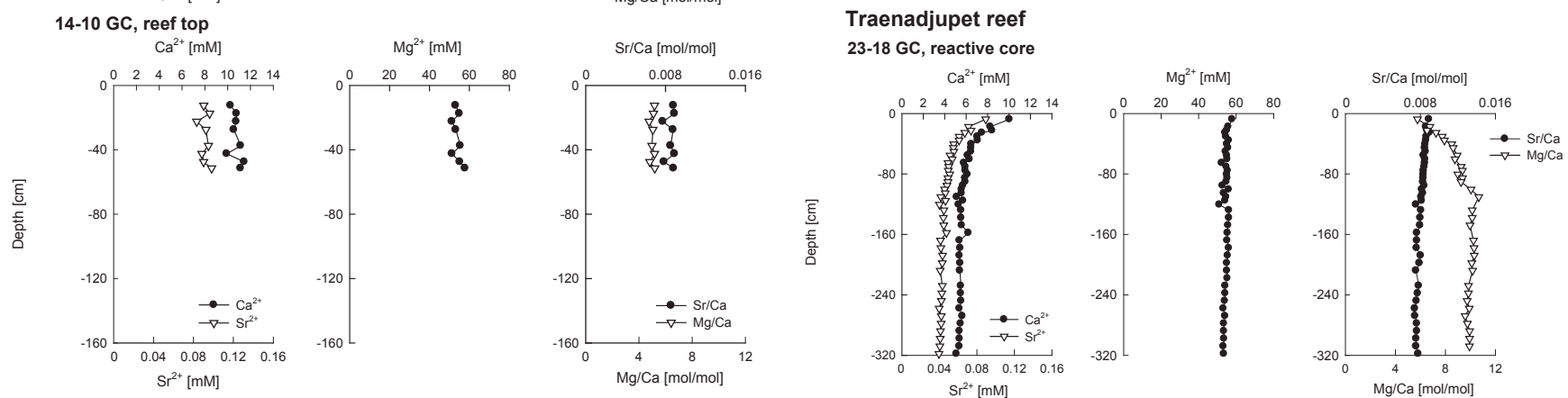
15-3 GC, coral rubble zone
$\mathrm{Ca}^{2+}[\mathrm{mM}]$
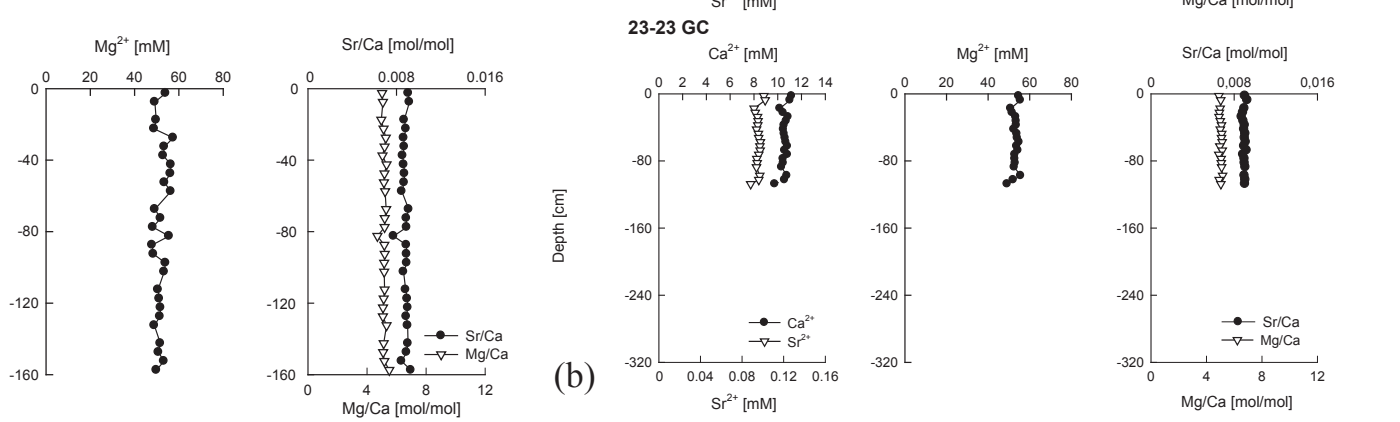

Fig. 7. Pore-water distribution of $\mathrm{Ca}^{2+}, \mathrm{Sr}^{2+}$ and $\mathrm{Mg}^{2+}, \mathrm{Sr} / \mathrm{Ca}$ ratio and $\mathrm{Mg} / \mathrm{Ca}$ ratio (a) in cores $14-8 \mathrm{GC}, 14-10 \mathrm{GC}$ and $15-3 \mathrm{GC}$ from Røst Reef and (b) in cores 23-18 GC and 23-23 GC from Traenadjupet Reef.

Thamdrup and Canfield, 1996). For instance, Kostka et al. (1999) detected SRR of up to $100 \mathrm{nmol} \mathrm{S} \mathrm{cm}^{-3} \mathrm{~d}^{-1}$ in surface sediments located north of the Lofoten Islands and warm-water carbonate reef sediments exhibit an order of magnitude higher SRR (Werner et al., 2006) than those detected for the Norwegian cold-water coral reef sediments. By comparison, these rates are in the range of rates reported in a study of carbon mineralization at Central Kvitøya Trench, Spitzbergen where long periods of ice coverage restrict primary production and limit the supply of organic carbon to the sediment (Vandieken et al., 2006).

Sulfate-reducing activities at all sites exhibit distinct, and often multiple zonations throughout the entire core. Such variability has been observed in other deep sediment profiles e.g. the Kattegatt (Iversen and Jørgensen, 1985), the Namibian upwelling area (Fossing et al., 2000), and the equatorial Pacific (Parkes et al., 2005). This zonation can be attributed to variable sedimentation and organic matter input. Only in the younger, top $70.5 \mathrm{~cm}$ of Traenadjupet core $23-18 \mathrm{GC}$ (Fig. 6b), sulfate reduction activities are constantly above the detection limit, thus we designated $23-18$ GC as the "reactive core". The $\mathrm{SO}_{4}^{2-}$ profile of core $23-18 \mathrm{GC}$ shown in Fig. $6 \mathrm{~b}$ displays the steepest gradient compared to the other cores where only small decreases in $\mathrm{SO}_{4}^{2-}$ concentration are evident. Elevated CRS values (Fig. 5) are also consistent with higher sulfate reduction activities in core $23-18$ GC than at other sites.

Dissimilatory $\mathrm{NO}_{3}^{-}$reduction is limited to a narrow zone close to the sediment surface, as indicated by $\mathrm{NO}_{3}^{-}$detection only in the top $10 \mathrm{~cm}$ of the sediment (data not shown). Only at the top of Røst Reef (14-10 GC) $\mathrm{NO}_{3}^{-}$was detected down to $32.5 \mathrm{~cm}$ sediment depth. Elevated $\mathrm{Mn}_{\text {diss }}$ and $\mathrm{Fe}_{\text {diss }}$ concentrations in the pore-water displayed in Fig. 6a and b, suggest the occurrence of dissimilatory $\mathrm{Fe}$ - and $\mathrm{Mn}$-oxide reduction as described by Lovley $(1987,1991)$. More likely, these elevated concentrations result from hydrogen sulfide reacting 

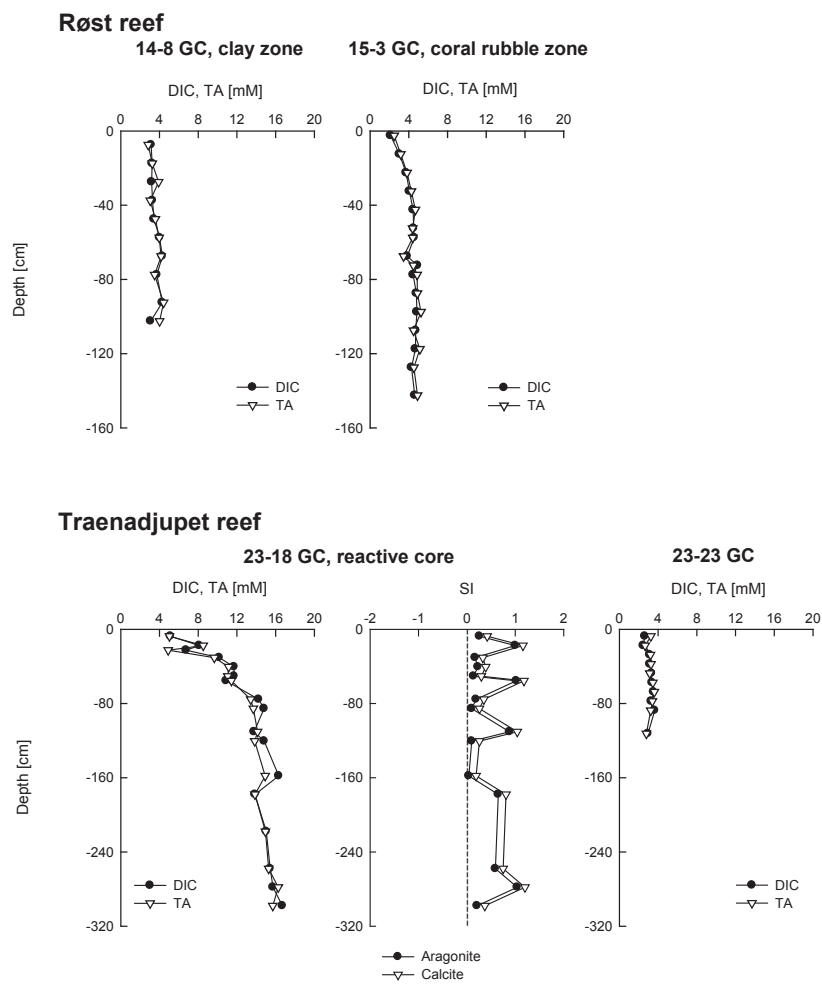

Fig. 8. Dissolved inorganic carbon (DIC) concentration and total alkalinity (TA) in the pore-water of cores 14-8 GC and 15-3 GC from Røst Reef and 23-18 GC and 23-23 GC from Traenadjupet Reef. Also shown are calculated saturation indices for aragonite and calcite with respect to the pore-water solution for core $23-18 \mathrm{GC}$. Values on the left side of the dotted line $(\mathrm{SI}=0)$ indicate undersaturation and values on the right side of the line indicate oversaturation of the respective mineral.

with the available reactive iron pool and iron/manganesecontaining minerals to form Fe-sulfide and dissolved metal species (Afonso and Stumm, 1992; Canfield et al., 1992; Yao and Millero, 1996). In Fig. 6a and b, distinct zones of $\mathrm{Mn}$ and Fe release into the pore-waters that directly correspond with zones of enhanced sulfate-reducing activity in cores at Traenadjupet (23-23 GC at $40 \mathrm{~cm}$ depth; 23-18 GC at $160 \mathrm{~cm}$ depth) and Røst Reef (15-3 GC throughout the core) are evident. Pore-water DIC concentrations shown in Fig. 8, which reflect the remineralization of organic carbon to $\mathrm{CO}_{2}$ in marine sediments, display values below $4.2 \mathrm{mM}$ and thus confirm low organic carbon mineralization in most reef sediments. Only in the top $140 \mathrm{~cm}$ of the "reactive core" $23-$ $18 \mathrm{GC}$, does sulfate reduction drive the DIC concentrations higher (up to $16.7 \mathrm{mM}$ ).

At Røst Reef differences in pore-water profiles of $\mathrm{SO}_{4}^{2-}$, $\mathrm{Fe}_{\text {diss }}, \mathrm{Mn}_{\text {diss }}$ and SRR (Fig. 6a) as well as $\mathrm{NO}_{3}^{-}$distribution between the investigated sites suggest that the reef zonation is not only evident in the type of facies coverage but to a certain extent also reflected in microbial-driven diagenesis. The reef top core $14-10 \mathrm{GC}$ shows a deep penetration of $\mathrm{NO}_{3}^{-}$

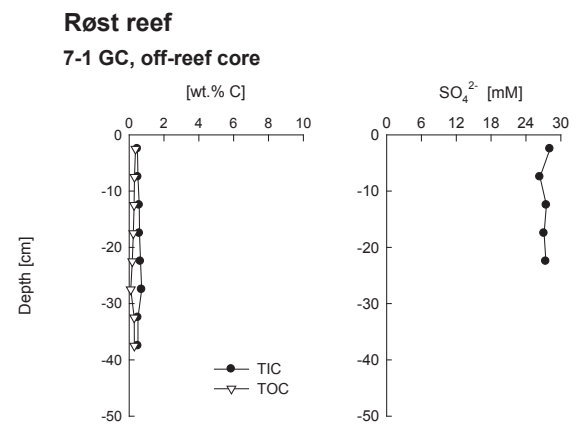

Traenadjupet reef 23-15 GC, off-reef core [wt.\% C]
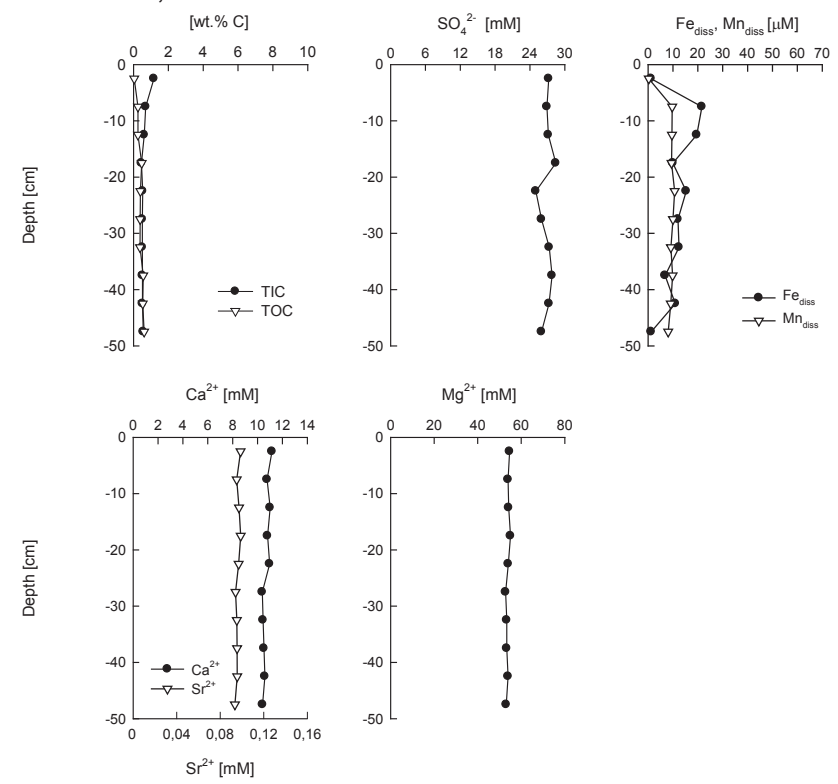

Fig. 9. Solid-phase total inorganic carbon (TIC) and total organic carbon (TOC) content and pore-water $\mathrm{SO}_{4}^{2-}$ concentration in offreef cores 7-1 GC and 23-15 GC. Also shown are pore-water distributions of $\mathrm{Ca}^{2+}, \mathrm{Sr}^{2+}$ and $\mathrm{Mg}^{2+}$ as well as $\mathrm{Fe}_{\text {diss }}$ and $\mathrm{Mn}_{\text {diss }}$ in core $23-15 \mathrm{GC}$.

and a steep increase in $\mathrm{Mn}_{\text {diss }}$ (Fig. 6a) at the bottom of the core. A layer of coarse rubble lacking a fine-grained fraction probably allowed the advective transport of $\mathrm{NO}_{3}^{-}$into the surface rubble and the extension of the suboxic zone to greater depth at the top of Røst Reef. Core 15-3 GC retrieved at the coral rubble zone displays a steeper decrease in $\mathrm{SO}_{4}^{2-}$ concentration and detectable SRR almost throughout the entire core compared to core $14-8 \mathrm{GC}$ from the clay zone where only scattered SRR data occur in the top $17.5 \mathrm{~cm}$. This indicates that despite the fact that TOC content does not differ significantly between the two sites, microbial activity in the coral rubble zone in closer proximity to the living part of the reef is slightly elevated compared to the clay zone. It remains to be further investigated which factors control these differences e.g. higher sedimentation rates or enhanced burial of reef-associated fauna, for example gorgonians or sponge remains that were found in the coral rubble zone core. 


\section{3-18 GC, reactive core}

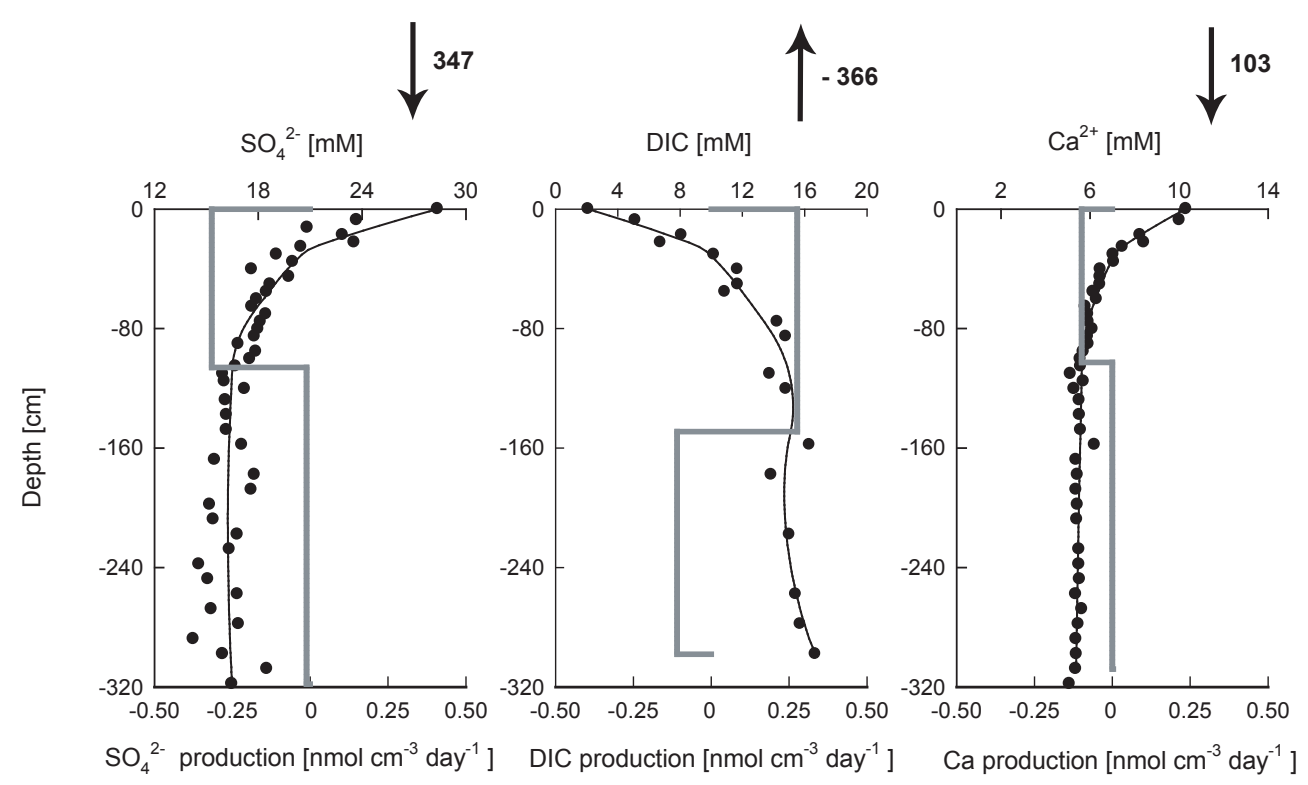

Fig. 10. Measured concentration of DIC, $\mathrm{SO}_{4}^{2-}$ and $\mathrm{Ca}^{2+}$ (dots), calculated least-square fit concentration profiles (black lines) and modeled rates of production (positive values) and consumption (negative values; grey lines). Calculated fluxes across the sediment-water interface are shown in $\mu \mathrm{mol} \mathrm{m}^{-2} \mathrm{day}^{-1}$; negative values indicate flux out of the sediment.

When comparing the on-reef cores with results from analyses of the off-reef cores (Fig. 9) it becomes evident that microbial-mediated processes in the reef sediments do exceed activity in the off-reef cores where pore-water constituents show only minor changes in concentration. Off-reef cores 7-1 GC (Røst Reef) and 23-15 GC (Traenadjupet Reef) display almost linear $\mathrm{SO}_{4}^{2-}$ profiles and no detectable sulfate reduction. Elevated $\mathrm{Fe}_{\text {diss }}$ and $\mathrm{Mn}_{\text {diss }}$ concentrations in core 23-15 GC indicate that dissimilatory Fe and Mn-reduction might proceed at low rates. Low average TOC contents $<0.4$ wt. \% detected in both cores suggest that organic matter supply to the sediments is very limited at these sites.

The low rates of anaerobic carbon mineralization observed in the investigated cold-water coral reef sediments may to a great extent be controlled by an extremely low flux of (labile) organic carbon to the sediments. We suggest that the coral framework structure overlaying the coralbearing sediments decouples the biogeochemical processes in the underlying reef sediments from the productive pelagic ecosystem (Fig. 11). The reefs are characterized by a large number of reef-framework-associated benthic suspension feeders (e.g. cnidarians, poriferans, mollusks) that can directly filter and remove organic particles from the water column (Jensen and Frederiksen, 1992; Jonsson et al., 2004), thereby acting as a sink for organic matter and reducing its supply to the reef sediments. This contrasts with the situation observed in the Darwin Mounds in the Rockall Trough where deep-water coral communities have colonized sandy surfaces. There, Kiriakoulakis et al. (2004) observed that echiuran worms effectively transport organic matter through conveyer-belt feeding into the sandy surface sediments. Within the clay-rich surfaces of the Norwegian reefs, bioturbation into deeper sediment layers appears to be minimal.

Carbon turnover by microbial respiration within interior coral frameworks is an important process during organic carbon diagenesis in warm-water coral reefs (Sansone et al., 1988; Tribble et al., 1990). Similarly, oxygen sensor measurements conducted at Røst Reef indicate low oxygen concentrations in the water column close to the reef surface (A. Purser, personal communication, 2008). Microbial oxygen consumption rates in the water column are also elevated close to the reef surface (Wild et al., 2008). Oxic microbial respiration may therefore be of greater importance in coldwater coral reef environments than in other high-latitude shelf areas, where it is generally regarded as a minor mineralization pathway (3.6-17.4\% of the total organic carbon oxidation, Canfield et al., 1993). Aerobic respiration in the overlying water column and living coral framework limits the amount of organic carbon reaching the sediment due to a rapid recycling of labile "fresh" material. Moreover, this process also alters the quality of the organic material reaching the sediment, leaving a large fraction of refractory "old" material that is inefficiently degraded under anoxic conditions (Hulthe et al., 1998).

Low methane concentrations $(<1 \mu \mathrm{M})$ at all investigated sediment depths in both coral reefs (data not shown) do not provide evidence for a coupling of cold-water coral reef 
distribution and the appearance of hydrocarbon seepage at the Mid-Norwegian cold-water coral reefs as previously suggested (Henriet et al., 1998; Hovland et al., 1998; Hovland and Risk, 2003; Hovland and Thomsen, 1997). The reefs are also underlain by very compact glacial clays, which inhibit the flux of deeper seated hydrocarbons into the post-glacial deposits. The glacial deposits furthermore represent a hard substrate, which the corals need for colonization (Frederiksen et al., 1992). Both reefs are located on elevated positions exposed to high current velocities that deliver nutrients and organic matter to the corals and inhibit sediment burial. Several studies have shown that these conditions promote the settlement and growth of cold-water corals (De Mol et al., 2002; Frederiksen et al., 1992; Freiwald, 2002; Mortensen et al., 2001; Roberts et al., 2006; Wheeler et al., 2007; White, 2007a). Furthermore, Dullo et al. (2008) showed that both reefs are located in water masses of a density of $27.5 \pm 0.15 \mathrm{~kg} / \mathrm{m}^{3}$ which seems to be a prerequisite for coral development and growth. We conclude that these external current- and density-controlled mechanisms control coral reef distribution and growth at the investigated reefs.

\subsection{Sulfate, metal and carbonate dynamics}

Sulfate reduction is an ongoing process in the coral reefassociated sediments, although hydrogen sulfide could not be detected in the pore-water. Hydrogen sulfide produced during sulfate reduction readily reacts with reactive iron minerals as well as with dissolved Fe constituents to form iron sulfide minerals that principally occur in these sediments as pyrite (CRS fraction). The sequential iron extractions reveal a large pool of reactive $\mathrm{Fe}-(\mathrm{oxyhydr})$ oxides $\left(\mathrm{Fe}_{\mathrm{ox} 1}\right.$ and $\mathrm{Fe}_{\mathrm{ox} 2}$; Fig. 4) such as ferrihydrite, lepidocrocite and goethite, which are characterized by very short half-lives with respect to their reaction with hydrogen sulfide (Canfield et al., 1992; Poulton et al., 2004).

The removal of hydrogen sulfide from the pore-water by reactive iron minerals has consequences for the coupling between dissimilatory sulfate reduction and pore-water carbonate dynamics. Depending on the magnitude of sulfate reduction and the initial value of pore-water $\mathrm{pH}$, the accumulation of sulfide and DIC in the pore-water may decrease the $\mathrm{pH}$ below carbonate saturation, which may lead to carbonate dissolution (Ben-Yaakov, 1973; Gardner, 1973). The oxidation of hydrogen sulfide strongly enhances this process (Walter and Burton, 1990; Walter et al., 1993). Sulfate reduction linked to carbonate dissolution accounts for significant carbonate losses at modern platform carbonate sediments off Florida and at Tahitian warm-water coral reefs (Ku et al., 1999; Tribble, 1993; Walter et al., 1993; Walter and Burton, 1990). However, if a sufficient pool of reactive iron minerals is present in the sediment, dissolved sulfide reduces ferric iron and precipitates as iron-monosulfides (FeS), intermediate ironsulfide species, and pyrite (Afonso and Stumm, 1992; Berner, 1984; Morse et al., 1992; Pyzik and Sommer, 1981;
Rickard and Luther, 2007; Wilkin and Barnes, 1996). The reductive dissolution of iron oxides is a strong proton consuming process. This buffers the carbonic acid system above carbonate undersaturation and carbonate dissolution is inhibited. The described mechanism depends on the amount of produced sulfide as well as on the availability of reactive $\mathrm{Fe}$ (oxyhydr)oxides. At the investigated reefs both factors seem to contribute to a well-buffered pore-water system and may explain the excellent preservation of cold-water coral fragments. A similar mechanism has been proposed to enhance coral preservation in cold-water coral mound systems drilled in IODP Expedition 307 (Ferdelman et al., 2006).

Linear pore-water $\mathrm{Mg}^{2+}, \mathrm{Ca}^{2+}$ and $\mathrm{Sr}^{2+}$ profiles and constant $\mathrm{Mg} / \mathrm{Ca}$ and $\mathrm{Sr} / \mathrm{Ca}$ ratios in the sediment cores investigated in the present study (Fig. 7a and b) further suggest the absence of extensive net carbonate dissolution. Moreover, in core $23-18 \mathrm{GC}$, decreasing $\mathrm{Ca}^{2+}$ and $\mathrm{Sr}^{2+}$ concentrations in the sulfate reduction zone indicate ongoing syn-depositional carbonate precipitation commonly expressed in the form:

$\mathrm{Ca}^{2+}+2 \mathrm{HCO}_{3}^{-} \rightarrow \mathrm{CaCO}_{3}+\mathrm{H}_{2} \mathrm{O}+\mathrm{CO}_{2}$

This process is the result of carbonate supersaturation caused by the production of bicarbonate via sulfate reduction. Similar trends in DIC and total alkalinity profiles of core 23 18 GC suggest that the production of bicarbonate (the dominant DIC species at the pore-water $\mathrm{pH}$ modeled with the PHREEQC program) entirely accounts for the rise in total alkalinity. The decreasing $\mathrm{Sr}^{2+}$ concentration associated with the decrease in $\mathrm{Ca}^{2+}$ was probably either the result of the incorporation of $\mathrm{Sr}^{2+}$ into the precipitating calcium carbonate species or due to an adsorption of $\mathrm{Sr}^{2+}$ onto freshly formed carbonate minerals. Changes in the $\mathrm{Sr} / \mathrm{Ca}$ ratio may suggest that the mineralogy of the precipitating mineral changed with depth, and an increasing amount of $\mathrm{Sr}^{2+}$ was incorporated into the crystal structure or adsorption was enhanced in deeper sediment layers. Calculations of the pore-water carbonate saturation index for aragonite and calcite shown in Fig. 8 reveal that conditions were favorable for the precipitation of both minerals. Decreasing pore-water $\mathrm{Sr}^{2+}$ concentration and a constant $\mathrm{Mg}^{2+}$ profile in the upper part of core 23-18 GC suggest that authigenic precipitation of aragonite may be occurring. $\mathrm{Sr}^{2+}$ is more frequently substituted in the aragonite structure while $\mathrm{Mg}^{2+}$ is more frequently incorporated in the calcite structure (Morse et al., 2007).

\subsection{Stoichiometry of the diagenetic processes}

Attempts are often made to deduce an overall net reaction stoichiometry of the main biogeochemical processes in sediments during early diagenesis. The mineralization of organic matter via sulfate reduction coupled to iron reduction in marine sediments can be expressed as follows:

$$
\begin{aligned}
6 \mathrm{SO}_{4}^{2-} & +{ }^{12} /{ }_{106}\left(\mathrm{CH}_{2} \mathrm{O}\right)_{106}\left(\mathrm{NH}_{3}\right)_{16}\left(\mathrm{H}_{3} \mathrm{PO}_{4}\right)+3 \mathrm{Ca}^{2+}+4 \mathrm{FeOOH} \\
& \rightarrow 6 \mathrm{HCO}_{3}^{-}+3 \mathrm{CO}_{2}+3 \mathrm{CaCO}_{3}+2 \mathrm{FeS}_{2}+2 \mathrm{FeS} \\
& +192 / 106 \mathrm{NH}_{3}+{ }^{12} / 106 \mathrm{H}_{3} \mathrm{PO}_{4}+11 \mathrm{H}_{2} \mathrm{O}
\end{aligned}
$$



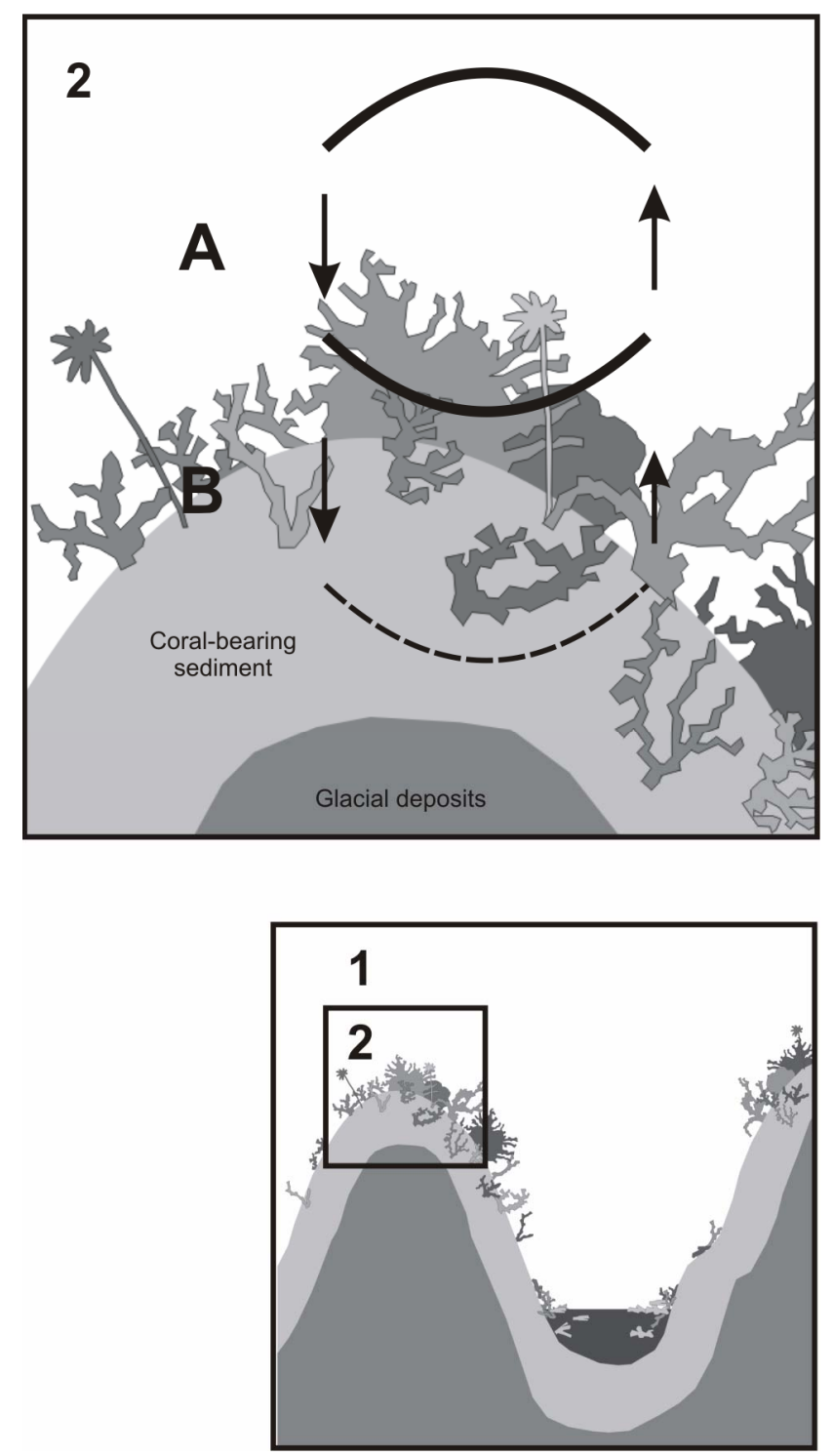

Fig. 11. Model of the two major zones of organic matter mineralization in Norwegian cold-water coral reefs: (A) the complex reef surface-framework and (B) the underlying carbonate-rich, coral fragment-bearing sediments.

With some assumptions, this stoichiometry can be assessed by comparing calculated fluxes across the sediment-water interface for $\mathrm{SO}_{4}^{2-}$, DIC and $\mathrm{Ca}^{2+}$ (Fig. 10) obtained through steady-state diagenetic modeling of the pore-water profiles using the PROFILE program (Berg et al., 1998). We selected the "reactive core" 23-18 GC to conduct this comparison because it displays the largest variations in the measured porewater constituents.

The stoichiometry given in Reaction (R2) implies a 2:1 ratio of $\mathrm{SO}_{4}^{2-}$ versus $\mathrm{Ca}^{2+}$ consumption and a $2: 3$ ratio for $\mathrm{SO}_{4}^{2-}$ consumption versus DIC production $\left(\mathrm{HCO}_{3}^{-}+\mathrm{CO}_{2}\right)$.
Because $1 / 4$ of produced $\mathrm{HCO}_{3}^{-}$is consumed by $\mathrm{CaCO}_{3}$ precipitation (Reaction R1), correction for the $\mathrm{Ca}^{2+}$ precipitated leads to a 1:2 ratio for sulfate consumption versus total DIC production. At the site where core $23-18$ GC was taken, the fluxes of $\mathrm{SO}_{4}^{2-}$ and $\mathrm{Ca}^{2+}$ across the sedimentwater interface are calculated to be $347 \mu \mathrm{mol} \mathrm{cm}^{-2} \mathrm{~d}^{-1}$ and $103 \mu \mathrm{mol} \mathrm{cm}^{-2} \mathrm{~d}^{-1}$, respectively, which gives a ratio of 3.4:1. This ratio exceeds by far the $2: 1$ ratio expressed in Reaction (R2) and suggests that less $\mathrm{Ca}^{2+}$ than expected is removed. The PROFILE program furthermore calculated a DIC flux across the sediment-water interface of $366 \mu \mathrm{mol} \mathrm{cm}{ }^{-2} \mathrm{~d}^{-1}$, which gives a total DIC flux (DIC in the pore-water $+\mathrm{Ca}^{2+}$ precipitated) of $469 \mu \mathrm{mol} \mathrm{cm}^{-2} \mathrm{~d}^{-1}$. In conclusion, the ratio of $\mathrm{SO}_{4}^{2-}$ flux versus total DIC flux calculated for this core is 1:1.4 instead of 1:2, which seems to indicate a decreased DIC flux. Assuming that all DIC production originates from sulfate reduction and is consumed by $\mathrm{CaCO}_{3}$ precipitation, a calculation of the expected DIC flux, using the carbon stoichiometry in Reaction (R2), would give a value of $591 \mu \mathrm{mol} \mathrm{cm}^{-2} \mathrm{~d}^{-1}$. Note that in Reaction (R2) all organic matter turnover proceeds via sulfate reduction, and dissimilatory metal oxide reduction is assumed to be minimal. However, even if microbial iron reduction is considered as a major pathway for organic matter mineralization, metal oxide reduction would also lead to enhanced, not less, DIC production.

Overall, the stoichiometry derived simply from the combination of the different single reaction equations may oversimplify the occurring processes. The representation of organic matter degraded within the sediment surface layer by Redfield stoichiometry as $\mathrm{CH}_{2} \mathrm{O}$ may not in all cases be correct (Hammond et al., 1996; Jahnke et al., 1994; Martin et al., 1987; Takahashi et al., 1985). These studies suggest that organic matter reaching the sediment may be, on average, more reduced than represented by the Redfield stoichiometry because it contains a large fraction of its carbon in $-\mathrm{CH}_{2}-$ groups. This leads to a shift of the overall organic matter composition towards a more complex mixture and reduces the ratio of oxidant (e.g. $\mathrm{O}_{2}$ or $\mathrm{SO}_{4}^{2-}$ ) to produced DIC from a 1:2 ratio towards a 1:1 ratio because for each mole $\mathrm{SO}_{4}^{2-}$ consumed an amount $<1$ mole of DIC is produced.

Based on the calculated fluxes the following stoichiometric equation describes the biogeochemical processes within core 23-18 GC:

$$
\begin{aligned}
6 \mathrm{SO}_{4}^{2-}+ & 12 /{ }_{106}\left(\mathrm{CH}_{2} \mathrm{O}\right)_{42.5}\left(\mathrm{CH}_{2}\right)_{31.8}\left(\mathrm{NH}_{3}\right)_{16}\left(\mathrm{H}_{3} \mathrm{PO}_{4}\right)+1.76 \mathrm{Ca}^{2+} \\
& +4 \mathrm{FeOOH}+1.84 \mathrm{H}^{+} \\
\rightarrow & 6.64 \mathrm{HCO}_{3}^{-}+1.76 \mathrm{CaCO}_{3}+2 \mathrm{FeS}_{2} \\
& +2 \mathrm{FeS}+{ }^{192} /{ }_{106} \mathrm{NH}_{3}+{ }^{12} / 106 \mathrm{H}_{3} \mathrm{PO}_{4}+11.6 \mathrm{H}_{2} \mathrm{O}
\end{aligned}
$$

The stoichiometry used for the organic material in Reaction (R3), therefore represents the average composition of the organic matter degraded during sulfate reduction in the cold-water coral reefs off Norway. This indicates that 
$\sim 57 \%$ of the degraded organic carbon was bound in the form of $\mathrm{CH}_{2} \mathrm{O}$ groups while $\sim 43 \%$ was bound as $-\mathrm{CH}_{2}$ - groups.

We cannot rule out that other processes are involved that would lead to an additional DIC consumption, and therefore, explain the lack in produced DIC. First, the precipitation of other carbonate minerals e.g. magnesium carbonates could occur. The conservative magnesium profile in the top $200 \mathrm{~cm}$, however, belies this possibility. Second, although we attributed all sulfate consumption to microbial sulfate reduction, other processes could lead to the observed decrease in pore-water sulfate concentration without producing DIC, such as the co-precipitation of sulfate with carbonate to form carbonate-associated sulfate (Staudt and Schoonen, 1995). However, the presence of sulfate reducing activity throughout the core as measured experimentally, suggests that dissimilatory sulfate reduction is the major process removing sulfate. Attributing the DIC deficit to a shift in the metabolized organic matter from carbohydrate-dominated to a more reduced alkyl stoichiometry is the most parsimonious explanation.

\section{Conclusions}

Highly productive cold-water coral reef ecosystems strongly influence biogeochemical processes in adjacent coralbearing sediments, although surprisingly, the influence acts as a negative feedback. This first biogeochemical study on recently deposited cold-water coral reef sediments allows the following conclusions:

1. Organic carbon turnover in the investigated cold-water coral reefs occurs in two major zones (Fig. 11): (A) the complex reef surface framework consisting of living and dead coral thickets and coral rubble and (B) the underlying carbonate-rich, coral fragment-bearing sediments. A rich benthic community of suspension feeders and a high organic matter turnover by oxic microbial respiration reduces the influx of organic matter into the underlying sediments. Therefore, the underlying sediments are characterized by extremely low rates of anaerobic carbon mineralization. The coral framework effectively decouples the reef sediments from the productive pelagic ecosystem.

2. Cold-water coral distribution at both reefs is not linked to hydrocarbon seepage. The underlying compact glacial deposits served as the initial hard substrate for coral settlement.

3. Stoichiometric calculations indicate the oxidation of organic matter with an average oxidation state below that of classic carbohydrate stoichiometries in these sediments. Thus, the limited amount of organic matter that reaches the sediment and that can be anaerobically metabolized appears to be rich in alkyl carbon.

4. Three tightly coupled diagenetic processes occur in these recent sediments: Microbial-mediated organic carbon mineralization by organoclastic sulfate reduction and by Fe-oxide reduction, reaction of produced hydrogen sulfide with dissolved Fe species and Fe-(oxyhydr)oxides to form Fe-sulfides, and authigenic carbonate precipitation instead of carbonate dissolution. The interplay of low rates of sulfate reduction and the availability of a sufficiently reactive iron pool in the siliciclastic sediments leads to a buffering of the pore-water carbonate system. This coupling ultimately prevents carbonate dissolution and favors authigenic carbonate precipitation. Overall, the sediments represent an excellent environment for cold-water coral skeleton preservation and provide a model for initial or surface diagenetic processes that may have occurred in cold-water carbonate mounds such as Challenger Mound.

Acknowledgements. We thank J.-P. Henriet for his support and A. Boetius and F. Hoffmann for organizing our participation on this research cruise. The efforts of the captain and crew of the $R / V$ Polarstern helped to make this cruise successful. We would like to thank Jan Helga Fossa and Pal Mortensen, Institute of Marine Research, Bergen, Norway and EU Hermes project for access to multibeam data in Traena Reef region. We are indebted to B. Schnetger and O. Dellwig for assistance with ICP-OES measurements at the ICBM, Oldenburg and the IOW, Warnemünde and T. Max for support during solid-phase analyses in the home laboratory. N. Riedinger, P. Meister and S. Schöttner are thanked for many fruitful discussions and M. Formolo for helpful comments on an earlier version of this manuscript. This work was funded by the German Research Foundation (DFG) grant Wi 2677/3-1 within ESF EuroDIVERSITY project MICROSYSTEMS and by the Max-Planck-Society (MPG).

The service charges for this open access publication have been covered by the Max Planck Society.

Edited by: D. Hammarlund

\section{References}

Afonso, M. D. and Stumm, W.: Reductive Dissolution of Iron(III) (Hydr)oxides by Hydrogen Sulfide, Langmuir, 8, 1671-1675, 1992.

Ben-Yaakov, S.: pH Buffering of Pore Water of Recent Anoxic Marine Sediments, Limnol. Oceanogr., 18, 86-94, 1973.

Berg, P., Risgaard-Petersen, N., and Rysgaard, S.: Interpretation of measured concentration profiles in sediment pore water, Limnol. Oceanogr. , 43, 1500-1510, 1998.

Berner, R. A.: Sedimentary Pyrite Formation, Am. J. Sci., 268, 123, 1970.

Berner, R. A.: Sedimentary Pyrite Formation - an Update, Geochim. Cosmochim. Ac., 48, 605-615, 1984.

Best, M. M. R., Ku, T. C. W., Kidwell, S. M., and Walter, L. M.: Carbonate Preservation in Shallow Marine Environments: Unexpected Role of Tropical Siliciclastics, J. Geol., 115, 437-456, 2007.

Boudreau, B. P.: Diagenetic Models and their Implementation: Modelling Transport and Reactions in Aquatic Sediments, Springer, Berlin, 1997. 
Boudreau, B. P. and Canfield, D. E.: A comparison of closed-system and open-system models for porewater $\mathrm{pH}$ and calcite-saturation state, Geochim. Cosmochim. Ac., 57, 317-334, 1993.

Broecker, W. S. and Clark, E.: Glacial-to-Holocene Redistribution of Carbonate Ion in the Deep Sea, Science, 294, 2152-2155, 2001.

Broecker, W. S. and Clark, E.: $\mathrm{CaCO}_{3}$ dissolution in the deep sea: Paced by insolation cycles, Geochem. Geophy. Geosy., 4, 1-13, 2003.

Canfield, D. E., Jørgensen, B. B., Fossing, H., Glud, R., Gundersen J., Ramsing, N. B., Thamdrup, B., Hansen, J. W., Nielsen, L. P., and Hall, P. O. J.: Pathways of organic carbon oxidation in three continental margin sediments, Mar. Geol., 113, 27-40, 1993.

Canfield, D. E., Raiswell, R., and Bottrell, S.: The Reactivity of Sedimentary Iron Minerals toward Sulfide, Am. J. Sci., 292, 659-683, 1992.

Cline, J. D.: Spectrophotometric Determination of Hydrogen Sulfide in Natural Waters, Limnol. Oceanogr., 14, 454-458, 1969.

Crowley, T. J.: Calcium-Carbonate Preservation Patterns in the Central North-Atlantic During the Last 150000 Years, Mar. Geol., 51, 1-14, 1983.

Damuth, J. E.: Echo Character of Norwegian-Greenland Sea: Relationship to Quaternary Sedimentation, Mar Geol., 28, 1-36, 1978.

De Mol, B., Van Rensbergen, P., Pillen, S., Van Herreweghe, K., Van Rooij, D., McDonnell, A., Huvenne, V., Ivanov, M., Swennen, R., and Henriet, J. P.: Large deep-water coral banks in the Porcupine Basin, southwest of Ireland, Mar. Geol., 188, 193231, 2002.

Dorschel, B., Hebbeln, D., Foubert, A., White, M., and Wheeler, A. J.: Hydrodynamics and cold-water coral facies distribution related to recent sedimentary processes at Galway Mound west of Ireland, Mar. Geol., 244, 184-195, 2007.

Dullo, C.-W., Flögel, S., and Rüggeberg, A.: Cold-water coral growth in relation to the hydrography of the Celtic and Nordic European continental margin, Mar. Ecol. Prog. Ser., 371, 165176, 2008.

Ferdelman, T. G., Kano, A., Williams, T., Henriet, J.-P., and the Expedition 307 Scientists. Proc. IODP, 307: Washington, DC (Integrated Ocean Drilling Program Management International, Inc.), doi:10.2204/iodp.proc.307.102.2006, 2006.

Ferdelman, T. G., Lee, C., Pantoja, S., Harder, J., Bebout, B. M., and Fossing, H.: Sulfate reduction and methanogenesis in a Thioploca-dominated sediment off the coast of Chile, Geochim. Cosmochim. Ac., 61, 3065-3079, 1997.

Fossing, H., Ferdelman, T. G., and Berg, P.: Sulfate reduction and methane oxidation in continental margin sediments influenced by irrigation (South-East Atlantic off Namibia), Geochim. Cosmochim. Ac., 64, 897-910, 2000.

Fossing, H. and Jørgensen, B. B.: Measurement of bacterial sulfate reduction in sediments: Evaluation of a single-step chromium reduction method, Biogeochemistry, 8, 205-222, 1989.

Frederiksen, R., Jensen, A., and Westerberg, H.: The distribution of the scleractinian coral Lophelia pertusa around the Faroe Islands and the relation to internal tidal mixing, Sarsia, 77, 157-171, 1992.

Freiwald, A., Henrich, R., and Pätzhold, J.: Anatomy of a deepwater coral reef mound from Stjernsund,West Finnmark, Northern Norway, in: Cool-Water Carbonates, edited by: James, N. P. and Clarke, J. A. D., SEPM, Spec. Publ., 56, 141-161, 1997.

Freiwald, A.: Reef-forming cold-water corals, in: Ocean Margin Systems, edited by: Wefer, G., Billett, D., Hebbeln, D., Jørgensen, B. B., Schlüter, M., and van Weering, T. C. E., Springer, Heidelberg, 365-385, 2002.

Gardner, L. R.: Chemical models for sulfate reduction in closed anaerobic marine environments, Geochim. Cosmochim. Ac., 37, 53-68, 1973.

Gieskes, J. M. and Rogers, W. C.: Alkalinity Determination in Interstitial Waters of Marine Sediments, J. Sediment. Petrol., 43, 272-277, 1973.

Hall, P. O. and Aller, R. C.: Rapid, small-volume, flow injection analysis for $\Sigma \mathrm{CO}_{2}$ and $\mathrm{NH}_{4}^{+}$in marine and freshwaters, Limnol. Oceanogr., 37, 1113-1119, 1992.

Hammond, D. E., McManus, J., Berelson, W. M., Kilgore, T. E., and Pope, R. H.: Early diagenesis of organic material in equatorial Pacific sediments: stoichiometry and kinetics, Deep-Sea Res. Pt. II, 43, 1365-1412, 1996.

Henriet, J.-P., De Mol, B., Pillen, S., Vanneste, M., Van Rooij, D., Versteeg, W., Croker, P. F., Shannon, P. M., Unnithan, V., Bouriak, S., and Chachkine, P.: Gas hydrate crystals may help build reefs, Nature, 391, 647-649, 1998.

Hovland, M. and Mortensen, P. B.: Norske korallrev og prosesser i havbunnen. John Grieg Forlag, Bergen, Norway, 1999.

Hovland, M., Mortensen, P. B., Brattegard, T., Strass, P., and Rokoengen, K.: Ahermatypic Coral Banks off Mid-Norway: Evidence for a Link with Seepage of Light Hydrocarbons, Palaios, 13, 189-200, 1998.

Hovland, M., Ottesen, D., Thorsnes, T., Fossa, J. H., and Bryn, P.: Occurrence and implications of large Lophelia-reefs offshore Mid Norway, in: Onshore - offshore relationships on the North Atlantic margin, edited by: Wandas, B., Nystuen, J.P., Eide, E. and Gradstein G., Norwegian Petroleum Society (NPF), Special Publications. Elsevier B.V., Amsterdam, 265-270, 2005.

Hovland, M. and Risk, M.: Do Norwegian deep-water coral reefs rely on seeping fluids?, Mar. Geol., 198, 83-96, 2003.

Hovland, M. and Thomsen, E.: Cold-water corals - are they hydrocarbon seep related?, Mar. Geol., 137, 159-164, 1997.

Hulthe, G., Hulth, S., and Hall, P. O. J.: Effect of oxygen on degradation rate of refractory and labile organic matter in continental margin sediments, Geochim. Cosmochim. Ac., 62, 1319-1328, 1998.

Iversen, N. and Jørgensen, B. B.: Anaerobic methane oxidation rates at the sulfate methane transition in marine sediments from Kattegat and Skagerrak (Denmark), Limnol. Oceanogr., 30, 944955, 1985.

Jahnke, R. A., Craven, D. B., and Gaillard, J. F.: The influence of organic matter diagenesis on $\mathrm{CaCO}_{3}$ dissolution at the deep-sea floor, Geochim. Cosmochim. Ac., 58, 2799-2809, 1994.

Jensen, A. and Frederiksen, R.: The fauna associated with the bankforming deep-water coral Lophelia pertusa (Scleractinaria) on the Faroe Shelf, Sarsia, 77, 53-69, 1992.

Jonsson, L. G., Nilsson, P. G., Floruta, F., and Lundälv, T.: Distributional patterns of macro- and megafauna associated with a reef of the cold-water coral Lophelia pertusa on the Swedish west coast, Mar. Ecol. Prog. Ser., 284, 163-171, 2004.

Jørgensen, B. B.: A comparison of methods for the quantification of bacterial sulfate reduction in coastal marine sediments. 1. Measurements with radiotracer techniques, Geomicrobiol. J., 
1, 11-27, 1978.

Jørgensen, B. B.: Mineralization of organic matter in the sea bed the role of sulphate reduction, Nature, 296, 643-645, 1982.

Kallmeyer, J., Ferdelman, T. G., Weber, A., Fossing, H., and Jørgensen, B. B.: A cold chromium distillation procedure for radiolabeled sulfide applied to sulfate reduction measurements, Limnol. Oceanogr.-Meth., 2, 171-180, 2004.

Kiriakoulakis, K., Bett, B. J., White, M., and Wolff, G. A.: Organic biogeochemistry of the Darwin Mounds, a deep-water coral ecosystem, of the NE Atlantic, Deep-Sea Res. Pt. I, 51, 1937-1954, 2004.

Kostka, J. E., Thamdrup, B., Glud, R. N., and Canfield, D. E.: Rates and pathways of carbon oxidation in permanently cold Arctic sediments, Mar. Ecol. Prog. Ser., 180, 7-21, 1999.

Ku, T. C. W., Walter, L. M., Coleman, M. L., Blake, R. E., and Martini, A. M.: Coupling between sulfur recycling and syndepositional carbonate dissolution: Evidence from oxygen and sulfur isotope composition of pore water sulfate, South Florida Platform, USA, Geochim. Cosmochim. Ac., 63, 2529-2546, 1999.

Laberg, J. S. and Vorren, T. O.: The Traenadjupet Slide, offshore Norway - morphology, evacuation and triggering mechanisms, Mar. Geol., 171, 95-114, 2000.

Laberg, J. S., Vorren, T. O., Mienert, J., Evans, D., Lindberg, B., Ottesen, D., Kenyon, N. H., and Henriksen, S.: Late Quaternary palaeoenvironment and chronology in the Traenadjupet Slide area offshore Norway, Mar. Geol., 188, 35-60, 2002a.

Laberg, J. S., Vorren, T. O., Mienert, J., Bryn, P., and Lien, R.: The Traenadjupet Slide: a large slope failure affecting the continental margin of Norway 4000 years ago, Geo.-Mar. Lett., 22, 19-24, 2002b.

Lindberg, B. and Mienert, J.: Postglacial carbonate production by cold-water corals on the Norwegian Shelf and their role in the global carbonate budget, Geology, 33, 537-540, 2005.

Lovley, D. R.: Organic matter mineralization with the reduction of ferric iron - A review, Geomicrobiol. J., 5, 375-399, 1987.

Lovley, D. R.: Dissimilatory Fe(III) and Mn(IV) Reduction, Microbiol. Rev., 55, 259-287, 1991.

Martin, J. H., Knauer, G. A., Karl, D. M. and Broenkow, W. W.: Vertex: carbon cycling in the northeast Pacific, Deep-Sea Res., 34, 267-285, 1987.

Mienis, F., de Stigter, H. C., White, M., Duineveld, G., de Haas, H., and van Weering, T. C. E.: Hydrodynamic controls on cold-water coral growth and carbonate-mound development at the SW and SE Rockall Trough Margin, NE Atlantic Ocean, Deep-Sea Res. Pt. I, 54, 1655-1674, 2007.

Milliman, J. D.: Production and accumulation of calcium carbonate in the ocean: Budget of a nonsteady state, Global. Biogeochem. Cy., 7, 927-957, 1993.

Morse, J. W., Arvidson, R. S., and Luttge, A.: Calcium Carbonate Formation and Dissolution, Chem. Rev., 107, 342-381, 2007.

Morse, J. W., Cornwell, J. C., Arakaki, T., Lin, S., and Huerta-Diaz, M.: Iron Sulfide and Carbonate Mineral Diagenesis in Baffin Bay, Texas, J. Sediment. Petrol., 62, 671-680, 1992.

Mortensen, P. B., Hovland, M., Brattegard, T., and Farestveit, R.: Deep-Water bioherms of the Scleractinian Coral Lophelia pertusa (L) at $64^{\circ} \mathrm{N}$ on the Norwegian Shelf: structure and associated megafauna, Sarsia, 80, 145-158, 1995.

Mortensen, P. B., Hovland, M. T., Fossa, J. H., and Furevik, D. M.: Distribution, abundance and size of Lophelia pertusa coral reefs in mid-Norway in relation to seabed characteristics, J. Mar. Biol. Assoc. UK, 81, 581-597, 2001.

Nordgulen, O., Bargel, T. H., Longva, O., and Ottesen, D.: A preliminary study of Lofoten as a potential World Heritage Site based on natural criteria, Geological Survey of Norway, 2006.

Ottesen, D., Rise, L., Knies, J., Olsen, L., and Henriksen, S.: The Vestfjorden-Traenadjupet palaeo-ice stream drainage system, mid-Norwegian continental shelf, Mar. Geol., 218, 175189, 2005.

Parkes, R. J., Webster, G., Cragg, B. A., Weightman, A. J., Newburry, C. J., Ferdelman, T. G., Kallmeyer, J., Jørgensen, B. B., Aiello, I. W., and Fry, J. C.: Deep sub-seafloor prokaryotes stimulated at interfaces over geological time, Nature, 436, 390-394, 2005.

Parkhurst, D. L. and Appelo, C. A. J.: User's guide to PHREEQC (Version 2): A computer program for speciation, batch-reaction, one-dimensional transport, and inverse geochemical calculations, U.S. Geological Survey Water-Resources Investigations Report, 99-4259, 310 pp., 1999.

Perry, C. T. and Taylor, K. G.: Inhibition of dissolution within shallow water carbonate sediments: impacts of terrigenous sediment input on syn-depositional carbonate diagenesis, Sedimentology, 53, 495-513, 2006.

Poulain, P. M., Warn-Varnas, A., and Niiler, P. P.: Near-surface circulation of the Nordic seas as measured by Lagrangian drifters, J. Geophys. Res.-Oceans., 101, 18 237-18 258, 1996.

Poulton, S. W. and Canfield, D. E.: Development of a sequential extraction procedure for iron: implications for iron partitioning in continentally derived particulates, Chem. Geol., 214, 209-221, 2005.

Poulton, S. W., Krom, M. D., and Raiswell, R.: A revised scheme for the reactivity of iron (oxyhydr)oxide minerals towards dissolved sulfide, Geochim. Cosmochim. Ac., 68, 3703-3715, 2004.

Pyzik, A. J. and Sommer, S. E.: Sedimentary iron monosulfides: kinetics and mechanism of formation, Geochim. Cosmochim. Ac., 45, 687-698, 1981.

Rickard, D. and Luther III, G. W.: Chemistry of Iron Sulfides, Chem. Rev., 107, 514-562, 2007.

Ridgwell, A. and Zeebe, R. E.: The role of the global carbonate cycle in the regulation and evolution of the Earth system, Earth. Planet. Sc. Lett., 234, 299-315, 2005.

Roberts, J. M., Wheeler, A. J., and Freiwald, A.: Reefs of the Deep: The Biology and Geology of Cold-Water Coral Ecosystems, Science, 312, 543-547, 2006.

Sansone, F. J., Andrews, C. C., Buddemeier, R. W., and Tribble, G. W.: Well-point sampling of reef interstitial water, Coral Reefs, 7, 19-22, 1988.

Schulz, H. D.: Quantification of early diagensis: Dissolved constituents in marine pore water, in: Marine Geochemistry, edited by: Schulz, H. D. and Zabel, M., Springer, Heidelberg, 85-128, 2000.

Seeberg-Elverfeldt, J., Schlüter, M., Feseker, T., and Kölling, M.: Rhizon sampling of porewaters near the sediment-water interface of aquatic systems, Limnol. Oceanogr.-Meth., 3, 361-371, 2005.

Soetaert, K., Hofmann, A. F., Middelburg, J. J., Meysman, F. J. R., and Greenwood, J.: The effect of biogeochemical processes on pH, Mar. Chem., 106, 380-401, 2007.

Staudt, W. J. and Schoonen, M. A. A.: Sulfate incorporation into 
sedimentary carbonates, in: Geochemical Transformations of Sedimentary Sulfur, edited by: Vairavamurthy, M. A., Schoonen, M. A. A., Eglinton, T. I., Luther III, G. W., and Manowitz, B., Acs Symposium Series, American Chemical Society, Washington DC, 332-345, 1995.

Takahashi, T., Broecker, W. S., and Langer, S.: Redfield Ratio Based on Chemical Data from Isopycnal Surfaces, J. Geophys. Res.-Oceans., 90, 6907-6924, 1985.

Thamdrup, B. and Canfield, D. E.: Pathways of carbon oxidation in continental margin sediments off central Chile, Limnol. Oceanogr., 41, 1629-1650, 1996.

Thorsnes, T., Fossa, J. H., and Christensen, O.: Deep-water coral reefs. Acoustic recognition and geological setting, Hydro International, 8, 26-29, 2004.

Titschack, J., Thierens, M., Dorschel, B., Schulbert, C., Freiwald, A., Kano, A., Takashima, C., Kawagoe, N., Li, X., and IODP Expedition 307 scientific party: Carbonate budget of a cold-water coral mound (Challenger Mound, IODP Exp. 307), Mar. Geol., 259, 36-46, 2009.

Tribble, G. W.: Organic Matter Oxidation and Aragonite Diagenesis in a Coral Reef, J. Sediment. Petrol., 63, 523-527, 1993.

Tribble, G. W., Sansone, F. J., and Smith, S. V.: Stoichiometric modeling of carbon diagenesis within a coral reef framework, Geochim. Cosmochim. Ac., 54, 2439-2449, 1990.

Vandieken V., Nickel, M., and Jørgensen, B. B.: Carbon mineralization in Artic sediments northeast of Svalbard: Mn(IV) and Fe(III) reduction as principal anaerobic respiratory pathways, Mar. Ecol. Prog. Ser., 322, 15-27, 2006.

Vecsei, A.: A new estimate of global reefal carbonate production including the fore-reefs, Global Planet. Change, 43, 1-18, 2004.

Walter, L. M., Bischof, S. A., Patterson, W. P., and Lyons, T. W.: Dissolution and recrystallization in modern shelf carbonates: evidence from pore water and solid phase chemistry, Philos. T. Roy. Soc. Lond. A, 344, 27-36, 1993.
Walter, L. M. and Burton, E. A.: Dissolution of Recent Platform Carbonate Sediments in Marine Pore Fluids, Am. J. Sci., 290, 601-643, 1990.

Wheeler, A. J., Beyer, A., Freiwald, A., de Haas, H., Huvenne, V. A. I., Kozachenko, M., Roy, K. O. L., and Opderbecke, J.: Morphology and environment of cold-water coral carbonate mounds on the NW European margin, Int. J. Earth Sci., 96, 37-56, 2007.

Werner, U., Bird, P., Wild, C., Ferdelman, T., Polerecky, L., Eickert, G., Jonstone R., Hoegh-Guldberg, O., and de Beer, D.: Spatial patterns of aerobic and anaerobic mineralization rates and oxygen penetration dynamics in coral reef sediments, Mar. Ecol. Prog. Ser., 309, 93-105, 2006.

White, M., Mohn, C., de Stigter, H., and Mottram, G.: Deep-water coral development as a function of hydrodynamics and surface productivity around the submarine banks of the Rockall Trough, NE Atlantic, in: Cold-water corals and ecosystems, edited by: Freiwald, A. and Roberts, J. M., Springer, Heidelberg, 503-514, 2005.

White, M.: Benthic dynamics at the carbonate mound regions of the Porcupine Sea Bight continental margin, Int. J. Earth Sci., 96, 1-9, 2007a.

White, M., Roberts, J. M., and van Weering, T. C. E.: Do bottomintensified dirunal tidal currents shape the alignment of carbonate mounds in the NE Atlantic?, Geo.-Mar. Lett., 27, 391-397, 2007b.

Wild, C., Mayr, C., Wehrmann, L., Schöttner, S., Naumann, M., Hoffmann, F., and Rapp, H. T.: Organic matter release by cold water corals and its implication for fauna-microbe interaction, Mar. Ecol. Prog. Ser., 372, 67-75, 2008.

Wilkin, R. T. and Barnes, H. L.: Pyrite formation by reactions of iron monosulfides with dissolved inorganic and organic sulfur species, Geochim. Cosmochim. Ac., 60, 4167-4179, 1996.

Yao, W. S. and Millero, F. J.: Oxidation of hydrogen sulfide by hydrous Fe(III) oxides in seawater, Mar. Chem., 52, 1-16, 1996. 